\title{
WestVirginiaUniversity
}

THE RESEARCH REPOSITORY @ WVU

Graduate Theses, Dissertations, and Problem Reports

2004

\section{Nutrition knowledge of high school athletes}

Charis Mitchell

West Virginia University

Follow this and additional works at: https://researchrepository.wvu.edu/etd

\section{Recommended Citation}

Mitchell, Charis, "Nutrition knowledge of high school athletes" (2004). Graduate Theses, Dissertations, and Problem Reports. 1986.

https://researchrepository.wvu.edu/etd/1986

This Thesis is protected by copyright and/or related rights. It has been brought to you by the The Research Repository @ WVU with permission from the rights-holder(s). You are free to use this Thesis in any way that is permitted by the copyright and related rights legislation that applies to your use. For other uses you must obtain permission from the rights-holder(s) directly, unless additional rights are indicated by a Creative Commons license in the record and/ or on the work itself. This Thesis has been accepted for inclusion in WVU Graduate Theses, Dissertations, and Problem Reports collection by an authorized administrator of The Research Repository @ WVU. For more information, please contact researchrepository@mail.wvu.edu. 
Nutrition Knowledge of High School Athletes

Charis Mitchell

\begin{abstract}
Thesis submitted to
School of Physical Education

At West Virginia University in partial requirement for fulfillment

of the degree of
\end{abstract}

\author{
Masters of Science \\ In \\ Athletic Training
}
Dr. Michelle A. Sandrey, PhD, ATC
Dr. Jack Watson, PhD
Betty Forbes, MA, RD, LD

School of Physical Education

Morgantown, WV

2004

Key words: athletes, nutrition knowledge, adolescent 


\section{ABSTRACT \\ Nutrition Knowledge of High School Athletes}

Charis Mitchell

Context: High school athletes may not be obtaining proper nutrition knowledge as they are beginning to form their life-long nutrition habits. Objective: The purpose of this study was to see where high school athletes are receiving their nutrition information and if high school student athletes acquire proper nutrition knowledge. Design: A prospective descriptive analysis of athletes' sources of nutrition information by year in school, gender, and primary sports. The athletes' scores on the nutrition knowledge questionnaire and the five groups of questions were analyzed by year in school, gender, and top 6 primary sports. Setting: A rural class AA high school in the southwest corner of Pennsylvania. Patients and other Participants: one hundred and thirty-nine high school athletes completed a nutrition knowledge questionnaire. The participants ranged in age from 14-18 years old (16 \pm 1.12 years) and consisted of freshman through seniors. The individuals participated in football, soccer, volleyball, cross-country, golf, cheerleading, wrestling, basketball, softball, baseball, and/or track and field. Interventions: A 27-item nutrition knowledge questionnaire was distributed to the athletes at a Class AA high school in the southwest corner of Pennsylvania during an assembly and at individual team meetings. Main Outcomes Measures: The main nutrition sources will be media, parents/family, and teammates. There will be a difference in year in school, gender and primary sports' score on the nutrition knowledge questionnaire. Results: The major sources of nutrition information came from doctors, parents/family, athletic trainers, coaches, TV, magazines, and health class. There was a statistical significance for year in school and teammates $\left(\chi^{2}=11.32, \mathrm{P}=.01\right)$, gender and athletic trainers $\left(\chi^{2}=28.71, \mathrm{P}=.000\right)$ and primary sports and athletic trainers $\left(\chi^{2}=24.79\right.$, $\mathrm{P}=.006)$. More sophomores did not choose teammates as a source of nutrition information. Males, especially those whose primary sport was football, cross-country, baseball, and wrestling chose the athletic trainers as a source of nutrition information. The primary and tertiary nutrition source was the doctor and the secondary nutrition source was TV. Thirty (21\%) participants answered 19 questions or more correctly on the nutrition knowledge questionnaire. There was no statistical significance for year in school, gender and top 6 primary sports on the nutrition knowledge questionnaire or on the five groupings of questions. To control for Type I error using a Bonferroni Correction Factor for the eighteen one-way ANOVAs, the level of significance was set at $\mathrm{P}=.003$ (.05/18). Juniors, females, and those whose primary sports were cross-country, soccer, and volleyball did better overall on the nutrition knowledge questionnaire. Sophomores and those whose primary sport was football, wrestling, and softball scored the lowest on the nutrition knowledge questionnaire. For the 5 groupings, most of the participants answered the diet questions correctly. A majority of the participants did not know the role of carbohydrates and protein in the body or that carbohydrates and protein have the same caloric value. There was also confusion about serving size for foods in the 5 food groups. The athletes are split on whether or not thirst is a reliable indicator for hydration status. Conclusions: High school athletes lack proper nutrition knowledge even though they are receiving most of their nutrition information from reputable sources such as doctors, athletic trainers, and health class. Athletes did receive some of their nutrition knowledge from TV, magazines and coaches. Athletes are confused about the role of carbohydrates and protein, and correct serving sizes. Nutrition education needs 
to focus on educating athletes about the importance of carbohydrates in athletics, servings sizes for the five food groups and hydration, so that athletes know how to plan a proper diet.

Key Words: athletes, nutrition knowledge, adolescent 


\section{ACKNOWLEDGEMENTS}

I would like to thank my Lord and Savior, Jesus Christ for giving me the grace and strength to complete this project.

A huge thank-you to Dr. Sandrey for putting up with me, for her dedication, and endless hours working with me to complete this project.

I would like to say thank-you to Dr. Watson and Professor Forbes for being on my committee, for their help and input on my thesis.

I would like to thank the administration, principal, assistant principal, athletic director, coaches, and athletes for allowing me conduct this study at their school.

A huge thank-you goes to my parents and family for their love, prayers, support, and encouragement throughout my college career.

I would like to say thank-you to my church family here and back home for their encouragement, and prayers.

A big thank-you goes to my roommate, Lori, who has put up with my mess while I was working on this project and for providing comic relief when I was stressed out.

I would like to thank those who reviewed the final draft of the questionnaire and those who copy edited my thesis. 


\section{TABLE OF CONTENTS}

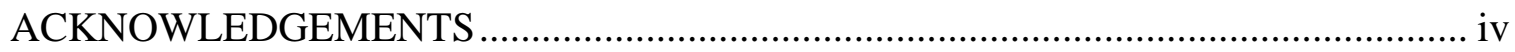

LIST OF TABLES..............................................................

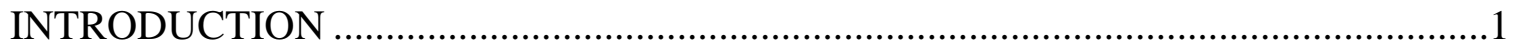

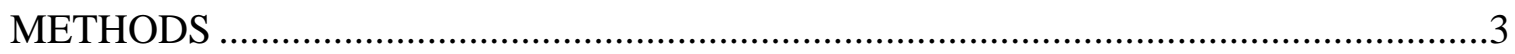

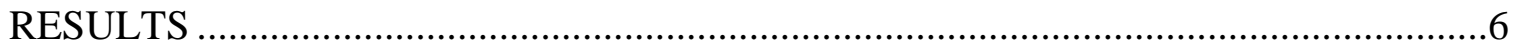

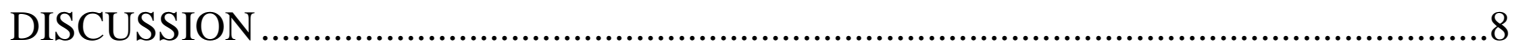

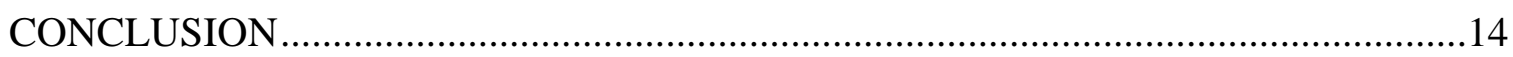

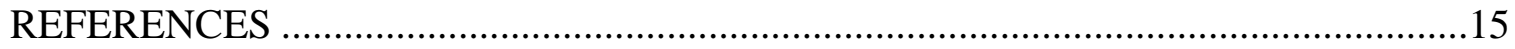

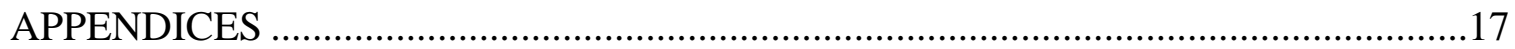

APPENDIX A. THE PROBLEM ..............................................................18

APPENDIX B. LITERATURE REVIEW .................................................24

APPENDIX C. ADDITIONAL METHODS ................................................49

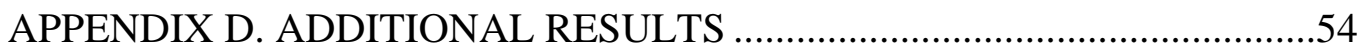

APPENDIX E. SUGGESTIONS FOR FUTURE RESEARCH ......................66

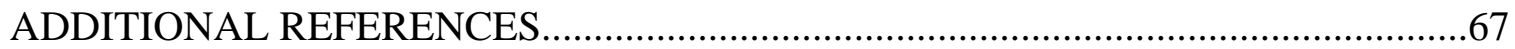




\section{LIST OF TABLES}

Table

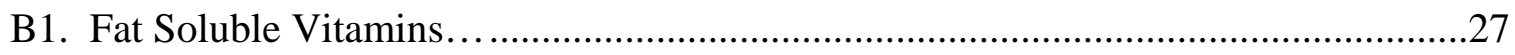

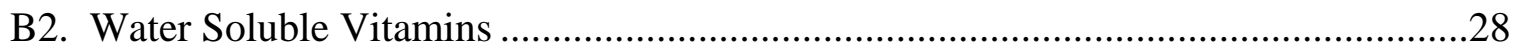

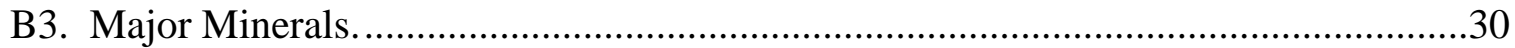

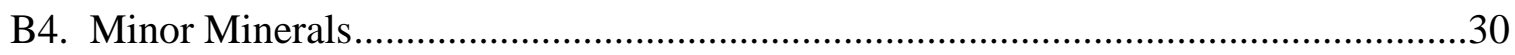

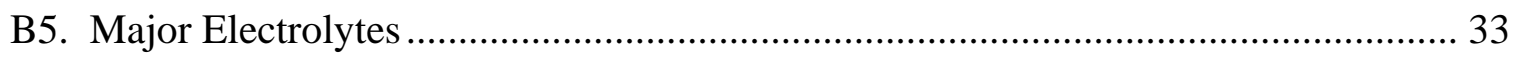

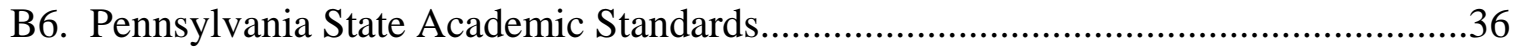

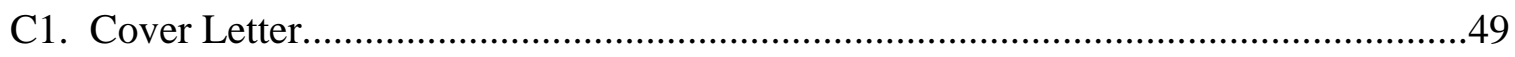

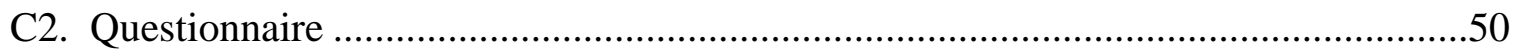

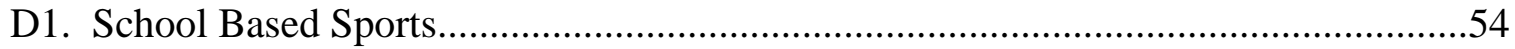

D2. Sources of Nutritional Knowledge ......................................................................54

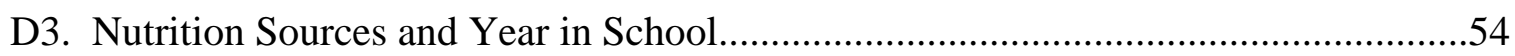

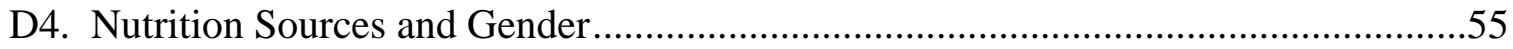

D5. Nutrition Sources and Primary Sports …............................................................55

D6. Primary, Secondary, and Tertiary Nutrition Source ............................................56

D7. Descriptive Statistics for Number Correct by Year in School and Primary Sports ...56

D8. Descriptive Statistics for 5 Groupings by Year in School .....................................57

D9. Descriptive Statistics for 5 Groupings by Gender .............................................57

D10. Descriptive Statistics for 5 Groupings by Primary Sports ...................................58

D11. ANOVA Results for Total Number Correct by Year in School, Gender and Top 6 Primary

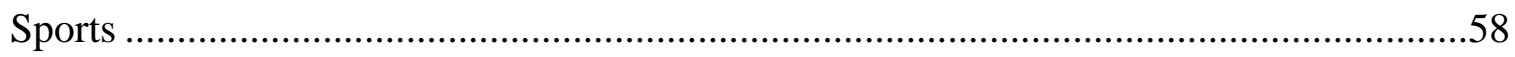

D12. Tukey’s Post-hoc Test for Number Correct by Year in School ..............................59

D13. Tukey’s Post-hoc Test for Number Correct by Top 6 Primary Sports ...................59

D14. ANOVA Results for Number Correct for the 5 Groupings by Year in School, Gender, and

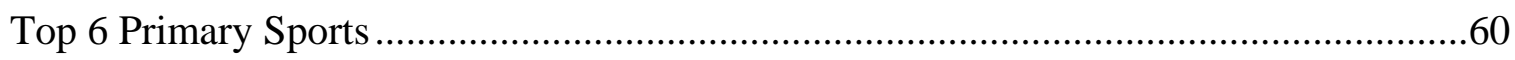

D15. Tukey’s Post-hoc Test for Group Number 1 by Year in School.............................60

D16. Tukey’s Post-hoc Test for Group Number 1 by Top 6 Primary Sports ..................61

D17. Tukey’s Post-hoc Test for Group Number 2 by Year in School............................61

D18. Tukey’s Post-hoc Test for Group Number 2 by Top 6 Primary Sports ..................62

D19. Tukey’s Post-hoc Test for Group Number 3 by Year in School.............................62 
D20. Tukey’s Post-hoc Test for Group Number 3 by Top 6 Primary Sports ..................63

D21. Tukey’s Post-hoc Test for Group Number 4 by Year in School............................63

D22. Tukey’s Post-hoc Test for Group Number 4 by Top 6 Primary Sports ...................64

D23. Tukey’s Post-hoc Test for Group Number 5 by Year in School.............................64

D24. Tukey’s Post-hoc Test for Group Number 5 by Top 6 Primary Sports ...................65 


\section{INTRODUCTION}

One way to educate high school athletes about proper nutrition knowledge is through nutrition education in the school system. Each states’ Department of Education establishes guidelines for including nutrition in a required health class. In the state of Pennsylvania, academic standards for health, safety, and physical education include a nutrition unit. Nutrition guidelines designed by the Pennsylvania Department of Education indicate what students should know by the $9^{\text {th }}$ and $12^{\text {th }}$ grade. By $9^{\text {th }}$ grade, students in Pennsylvania should be able to explain general nutrition knowledge, food groups, analyze nutrition factors, and eating disorders. By $12^{\text {th }}$ grade, students in Pennsylvania should be able to analyze factors that impact the nutrition choices of adults such as cost, food preparation, and food consumer skills. ${ }^{1}$

Even though schools are required to teach general nutrition information, high school athletes still continue to obtain their knowledge and understanding of nutrition practices from advertisements, coaches, parents/family, and/or fellow athletes. ${ }^{2,3,4,5}$ Athletes asked and received advice about diet and health mainly from their coaches ${ }^{2,5,6,7}$ but also from parents, ${ }^{3,4,5,6,7}$ doctors, ${ }^{2}$ and teammates. ${ }^{2}$ Parents, popular books and magazines are considered the be the number one nutrition source outside of school. However, general science, home economics, and health classes were chosen as the top nutrition source in school. ${ }^{3}$ It appears that high school students receive nutrition information from a variety of sources, but it is not known if the information they are receiving is accurate.

Unfortunately, even with nutrition education being taught in the schools, many athletes do not know what optimal nutrition ${ }^{8}$ is when planning their own diets. It is important for athletes to eat 6-11 servings of carbohydrates, 3-5 servings of vegetables, 2-4 servings of fruits, 3 servings of calcium-rich products, and 2 servings from high proteins sources. This allows the athlete to receive enough carbohydrates, proteins, fats, vitamins and minerals that are important 
for the body to be able to maintain normal everyday functions, provide repair capabilities, and provide energy for the athlete. Athletes need to drink plenty of water to replace fluids lost during practices or competitions and to prevent dehydration that can hinder athlete performance. .,10,11 $^{9}$ Few athletes know if they are consuming the Recommended Daily Allowance (RDA) for nutrients ${ }^{12}$ Seventy percent of the athletes studied did not eat $100 \%$ of their RDA for calcium and iron but consumed more than the RDA for vitamin A and C. ${ }^{12}$ Only 16 consumed the RDA for calcium. ${ }^{13}$ In a study of 330 athletes, more than $50 \%$ of the athletes believed that protein is the main source of energy for the muscles. More than $29 \%$ of the athletes studied knew the recommended amount of carbohydrate intake, whereas only $11.7 \%$ knew the recommended percent of protein and fat from the total number of daily calories. ${ }^{6}$ More than $50 \%$ of the 328 athletes studied, knew carbohydrates and fat provide energy for the body. Majority of the athletes believed that vitamins and minerals supplements could provide energy. Ninety-five percent of the athletes knew that water should be ingested before, during, and after practices and competitions and $74 \%$ knew thirst is not an indicator of hydration status. ${ }^{14}$ More than $50 \%$ of the 31 football players studied believed that sports drinks are not an appropriate substitute for water to replace fluid losses. ${ }^{15}$

There have been several studies ${ }^{2,3,4,6,7,12,14,16,17,18,19,20}$ looking at athletes' nutrition knowledge. In most of the studies reported, however, the influence of health class on nutrition has not been explored. Furthermore, there have been no studies in the literature that have looked at how nutrition information from health class influences the dietary intake of athletes. High school athletes may be receiving nutrition information from advertisements that might not be a reliable source. This lack of proper nutrition knowledge is important because, at this age, they are starting to build their lifetime healthy eating habits. It is important that students become informed consumers through classes and participating in sports. Therefore, the purpose of this 
study is to note where high school athletes are getting their sources of nutrition information and if high school athletes acquire proper nutrition knowledge through the use of a nutrition knowledge questionnaire.

\section{METHODS}

The design of this study was a prospective descriptive analysis, which identifies the influences of nutrition sources and the nutrition knowledge of high school athletes by year in school, gender, and primary sport through the use of a nutrition knowledge questionnaire. For the first analysis, the independent variables were year in school (freshman, sophomore, junior, senior), gender (male and female) and primary sport of involvement (football, soccer, track, basketball, baseball, softball, wrestling, volleyball, cross-country, cheerleading, and golf). The dependent variables were nutrition sources (magazine, TV, books, coaches, athletic trainers, school nurses, doctors, parents/family, friends, teammates, dietitians, health class, and others). The second analysis for the questionnaire consisted of three factorial designs. A 1 x 4 factorial design was used for year in school (freshmen, sophomores, juniors, and seniors). The second factorial design was a $1 \times 2$ for gender (male and female). The third factorial design was 1 x 6

for top six primary sports (football, soccer, track, basketball, baseball, and softball). The dependent variables were number correct on the nutrition knowledge questionnaire and number correct on the five groups (carbohydrates and proteins, fruits and vegetables, vitamins and minerals, diet, and hydration).

\section{Subjects}

The participants $(\mathrm{N}=139)$ for the study were athletes from a four-year rural high school in Pennsylvania. They ranged in age from 14 to 18 years with a mean age of $16 \pm 1.12$ years. Thirty-two of the participants were freshmen (23\%), thirty-eight sophomores (27.3\%), forty-five 
juniors (32.4\%), and twenty-five seniors (17.3\%). Eighty-two (59\%) were males and fifty-seven (41\%) were females. The athletes were participants in football, soccer, volleyball, cross-country, golf, cheerleading, wrestling, basketball, softball, baseball, and/or track and field. See Table D1. for percentages. The school district superintendent, high school principal, athletic director, and the coaches of their respective sports granted permission to use the athletes at the high school. The "Nutritional Knowledge of High School Athletes" questionnaire was approved by the West Virginia University Institutional Review Board for the protection of human subjects.

\section{Instrumentation}

A questionnaire (Table C2) consisting of 12 demographic questions and 27 multiple-choice $(\mathrm{n}=12)$ and true/false $(\mathrm{n}=15)$ questions were developed for this study. The questions were divided into sections, which represent information related to: 1) carbohydrates and protein, 2) fruits and vegetables, 3) vitamins and minerals, 4) diet, and 5) hydration. The content of the questionnaire was based upon general nutrition knowledge, which the athlete should have obtained in his/her health class.

The investigator designed the questionnaire based on elements from four other nutrition

knowledge questionnaires. ${ }^{2,4,15,21}$ The questions were selected based on conversations with physical education teachers and state guidelines for nutrition education. One psychometric expert, one registered and licensed dietitian, one physical education teacher/exercise physiologist and two certified athletic trainers with nutrition expertise and experience working with high school athletes examined the final questionnaire for clarity, order, and selections, as well as for content and face validity. The questionnaire was also examined by three certified athletic trainers for content and face validity. 
Procedures

Questionnaires were distributed to athletes at a rural Class AA high school in the southwestern corner of Pennsylvania. A cover letter was included to explain the purpose of the study to participants and indicated their rights as participants. The questionnaires were distributed during an assembly and at individual team meetings. The cover letter and directions were read aloud while the participants read along silently. Following the explanation, the participants were allowed time to complete the questionnaire. After the questionnaire was finished, participants went to the front of the room and placed the questionnaire in one of the envelopes. The primary investigator collected the envelopes after the participants left the room.

\section{Data Analysis}

For data analysis purposes, the nutrition knowledge questions on the questionnaire were divided into five groups to reflect the areas of general nutrition knowledge, students had obtained from health classes. Questions 1-8 were placed in the carbohydrates and protein group. The fruits and vegetables group consisted of questions 9-13. The vitamin and minerals group consisted of question 14-17. Questions 18-23 and 27 were placed in the diet group, while questions 24-26 comprised the hydration group. Responses to the five groupings of questions were analyzed by year in school, grade, and primary sport.

\section{Statistical Analysis}

Descriptive statistics were used to report the school based sports, primary sports, nutritional knowledge sources, primary, secondary, and tertiary nutrition sources, and why the primary, secondary, and tertiary nutrition sources were helpful. A Chi-square Analysis was used to compare responses to nutrition sources by year in school, gender, and primary sport. The P value was set at $\mathrm{P} \leq .01$. A Multivariate Analysis of Variance (MANOVA) was not used 
because assumptions were violated. Eighteen One-Way Analysis of Variance (ANOVA's) were used to see if there was a statistical significance for number correct on the questionnaire and the 5 groupings of questions by year in school, gender, and primary sport. Tukey's post hoc comparisons were used where significance was indicated. To decrease the chance of a Type I error, a Bonferroni Correction Factor was used due to the number of ANOVA tests performed. The $\mathrm{P}$ value was determined by dividing by .05 by the 18 ANOVA's. The $\mathrm{P}$ value was set at $\mathrm{P} \leq$ .003. The Statistical Package for the Social Sciences (SPSS) for Windows (version 11.0, SPSS, Inc. Chicago, Ill) were used to analyze the demographic and nutrition knowledge questions.

\section{RESULTS}

Sport and Nutrition Sources

The athletes were asked to circle the sports they had participated in during the last school year. They were also asked to name their primary sport from a list of choices that included track, football, basketball, soccer, baseball, softball, wrestling, cheerleading, volleyball, cross-country, and golf. Percentages are listed in Table D1.

One hundred and thirty-seven (98.6\%) of the participants stated they took a health class their freshman year. Only one participant (.7\%) took health class during his/her sophomore year. There were no participants who took health class during their junior or senior year. One participant (.7\%) did not answer this question. The participants were asked if nutrition was a topic in their health class. One hundred and twenty participants (88\%) stated nutrition was discussed in their health class. Seventeen participants (12\%) said nutrition was not a topic in their health class. Two participants (1\%) left this question blank. Six participants (4.3\%) in this study attended additional nutrition classes, such as seminars or talks. 
The participants were asked to circle where they received their nutritional information from a list of choices that included doctors, athletic trainers, parents/family, coaches, TV, magazines, health class, friends, books, teammates, school nurses, dietitians, and others. Results are listed in Table D2. Chi-square Analysis found a statistical difference for teammates $\left(\chi^{2}=11.322, \mathrm{P}=\right.$ .010) for nutrition sources and year in school. Sophomores $(94 \%, n=36)$ indicated that teammates were not a good source of nutrition information. Additional results are listed in Table D3. When comparing gender, there was also a statistical significance for athletic trainers $\left(\chi^{2}=\right.$ 28.709, $\mathrm{P}=.000$ ) as a nutrition source. Based on percentages, males selected athletic trainers $(70.7 \%, \mathrm{n}=58)$ more than females $(24.6 \%, \mathrm{n}=14)$ as a source of nutrition information. Additional results are listed in Table D4. For primary sports, there was a statistical significance for athletic trainers $\left(\chi^{2}=24.788, \mathrm{P}=.006\right)$ as a nutrition source. The participants whose primary sport was football $(75 \%, n=21)$, cross-country $(71.4 \%, n=5)$, baseball (61.5\%, $n=8)$, and wrestling ( $85.7 \%$, $n=6$ ) selected athletic trainers as a source of nutrition information. In regard to food advertisements, eighty-eight participants (63.3\%) felt that food advertisements were not reliable. Additional results are listed in Table D5. No other analyses were significant.

The participants were asked to rank their primary, secondary, and tertiary nutrition sources as well as list reasons why nutrition sources are helpful. Doctors ( $\mathrm{n}=23,16.5 \%)$ were listed as the primary source of nutrition information followed by parents/family, athletic trainers, health class, magazines, and coaches. The secondary source of nutrition information was TV $(15.1 \%, \mathrm{n}=21)$ followed by coaches, athletic trainers, parents/family, books, doctors, and magazines. The tertiary nutrition information chosen was doctors $(13.7 \%, \mathrm{n}=19)$ followed by coaches, TV, parents/family, health class, athletic trainers and magazines. Overall, most of the participants 
wrote that nutrition sources were helpful for health reasons, nutrition sources are knowledgeable, and nutrition sources care about them. Results are listed in Table D6.

Questionnaire

A total of 30 participants (21.5\%) answered 19 or more questions correctly on the nutritional knowledge questionnaire. The mean score on the nutritional knowledge questionnaire was 15.28 \pm 3.9 , with a range from 6 to 23 questions answered correctly. The mean score for males was $15.07 \pm 3.9$ and the mean score for females was $15.58 \pm 3.9$. Juniors scored the highest while the sophomores scored the lowest. Cross-country, soccer, and volleyball scored highest but football, wrestling, and softball scored the lowest. The mean score for year in school and primary sport are listed in Tables D7. The mean score for the carbohydrates and protein group was $3.84 \pm$ $1.45,2.54 \pm 1.13$ for the fruit and vegetables group, $2.15 \pm 1.12$ for the vitamins and minerals group, $2.07 \pm 1.55$ for the diet group, and $1.73 \pm .78$ for the hydration group. Additional results are found in Table D8-10. There was no statistical difference between year in school $\left(\mathrm{F}_{1,3}=2.77\right.$, $\mathrm{P}=.04)$, gender $\left(\mathrm{F}_{1,1}=.573, \mathrm{P}=.45\right)$, and top 6 primary sports $\left(\mathrm{F}_{1,5}=1.67, \mathrm{P}=.15\right)$ for number of questions answered correctly on the questionnaire. Results are listed in Table D11. There was no statistical significance between year in school, gender, and top 6 primary sports for the number questions answered correctly for the five groups. Results are listed in Table D14.

\section{DISCUSSION}

The purpose of this study was to find where they receive their nutrition knowledge and evaluate the nutrition knowledge of high school athletes through the use of a nutrition knowledge questionnaire. The questionnaire was further broken down into five groups and the number correct for the five different groups were analyzed by year in school, gender and primary sport. 
Sport and Nutrition Sources

It was hypothesized that a majority of the participants received their nutrition knowledge information from media sources such as magazines and TV, along with parents/family, friends, and teammates. This study revealed that a majority of the participants chose doctors, athletic trainers, parents/family, coaches, and health class as their nutrition knowledge sources, therefore the hypothesis was rejected. This study’s results are similar to the Witta ${ }^{2}$ study, in which nutrition sources came from coaches, parents, doctors, and family. ${ }^{2}$ However, this study’s results are different from the Cupisti study, ${ }^{4}$ in which nutrition knowledge sources mainly came from parents, media, and teammates. Even though media sources such as TV and magazines were not the most frequently chosen source, many of the participants use them for nutritional information. In this study, TV was chosen as the secondary nutrition source and frequently for the tertiary nutrition sources. The same was true for magazines. Parents/family were frequently chosen as one of the primary, secondary, and tertiary nutrition sources, which was consistent with the Witta ${ }^{2}$ and Cupisti ${ }^{4}$ studies. The biggest difference between this study and the Cupisti study ${ }^{4}$ was that the participants in this study did not choose teammates very often or list them as one of their nutrition sources. Coaches were often chosen as a source of nutrition information, which agrees with other studies ${ }^{5,6}$ naming the coach as a source of information. The results of this study differ from the Jacobson et al study ${ }^{6}$ findings in that most of the athletes received nutrition knowledge from strength coaches, athletic trainers, coaches, classes and magazines and not as often from doctors, parents, or TV. ${ }^{6}$

The Witta ${ }^{2}$ and Cupisiti ${ }^{4}$ studies did not have athletic trainers as being a source of nutrition information. In this study, athletic trainers were the third highest source chosen overall and were chosen frequently for the primary, secondary, and tertiary nutrition sources. Males, especially 
those whose primary sport was football, tend to choose the coaches and athletic trainers as the primary, secondary, and tertiary nutrition sources. Jacobson et $\mathrm{al}^{6}$ found that males received more nutrition information from athletic trainers than females. ${ }^{6}$ Another study also found that football players use athletic trainers for nutrition information. ${ }^{19}$ A possible reason why the participants choose athletic trainers as a nutrition source is that the athletic trainers at this high school are very proactive about nutrition. They also frequently gave out nutrition information but on a more consistent basis with football, mainly during football camp. Freshmen chose health class as one of their top nutrition sources but the older participants chose coaches, athletic trainer, and parents/family. Most of the participants took a health class during their freshman year that teaches nutrition, which may be a reason that freshman selected health class over the other choices. However, upper classmen have not taken a health class since freshman year so they look to use other nutrition sources for nutrition information.

\section{Questionnaire}

It was hypothesized that there would be a statistical significance between year in school, gender, and primary sports for the score on the nutrition knowledge questionnaire. The hypothesis was rejected because no statistical significance was found. It was also hypothesized that there would be a statistical significance between year in school, gender, and primary sports for the score on the five groupings. The hypothesis was rejected because no statistical significance was found.

Of the 139 participants that completed the questionnaire, 30 athletes answered 19 questions or above correctly with a mean score of $15.28 \pm 3.87$. The overall percent of this questionnaire (56.\%) was similar to the Douglas and Douglas, ${ }^{3}$ and Witta and Stombaugh studies on high school athletes' nutrition knowledge. ${ }^{2,3}$ In the Douglas and Douglas ${ }^{3}$ study, the mean score on 
the questionnaire was 26.40 (55\%). Their questionnaire was made up of questions dealing with carbohydrates, proteins, fats, vitamin and minerals and common misconceptions about nutrition. In the Witta and Strombaugh ${ }^{2}$ study, the mean score on the nutrition knowledge test was $66 \%$. The nutrition test in the Witta and Strombaugh ${ }^{2}$ was a modified version of another nutrition test that includes general nutrition knowledge and nutrition for athletes. Only two questions for this nutrition knowledge questionnaire came from Witta and Strombaugh. ${ }^{2}$ Even though, some of the nutrition topics were similar in other questionnaires, it is not known if the questions were easier or more difficult then this study's questions. ${ }^{2,3}$

An interesting finding is that juniors scored the best overall, but they received most of their nutrition knowledge from magazines and TV. Although not significant, females did better on the nutrition knowledge which is consistent with the Douglas and Douglas study. ${ }^{3}$ Even though, results from primary sport and total number correct was not significant, those athletes whose primary sport was cross-country, volleyball, and soccer had the highest mean score. Football athletes, who had obtained the most nutrition information from athletic trainers, had the lowest mean score. The results of this study agreed with the Douglas and Douglas ${ }^{3}$ study, which found that cross-country athletes scored higher on the nutritional knowledge test while football athletes had the lowest mean score. ${ }^{3}$

According to the Pennsylvania State Academic Standards, by $6^{\text {th }}$ grade students should know the caloric content of foods. ${ }^{1}$ However, $82 \%$ of the participants studied did not know that carbohydrates and protein have the same number of calories. The results of this study matched two other studies where less than 50\% correctly answered that carbohydrates and protein have the same caloric value. ${ }^{6,15}$ This study found that $72 \%$ felt that eating high amounts of protein will help increase muscle size and $79.1 \%$ felt that protein was the primary energy source for 
muscles. The results of this study were confirmed by the Jonnagaladda et $\mathrm{al}^{15}$ study that indicated more than $50 \%$ of the athletes felt that protein was the primary energy source and/or high amounts of protein will increase muscle size. ${ }^{15}$ The same thing was true of a 1986 study of adolescent gymnasts, who thought that protein was the main source of energy for the muscles. ${ }^{22}$ However, in two different studies, Schmalz ${ }^{16}$ and Rosenbloom ${ }^{14}$ found that athletes were divided on whether or not protein helped increase muscle size. Obviously, the participants are misinformed or uneducated about the role of carbohydrates in the body and especially for athletes. Athletes need a greater intake of carbohydrates for energy, ${ }^{9}$ especially for muscle activity during exercise. This misunderstanding or lack of knowledge about the role of carbohydrates can be harmful to the body and affect performance. ${ }^{9}$ The reason why the athletes do not know the role of carbohydrates and protein in the body is not really known since the majority of the participants received their nutrition information from reputable sources. The influences from TV, magazines, health stores, or parents/family might have contributed to this. Another reason is that the participants simply forgot the information from freshman year because this is something they do not review every year.

A majority of the participants knew the correct number of servings for each of the five food groups but most did not know what a serving size was for each group. Thirty-four percent answered correctly that a serving size for the protein group is three ounces of meat. Students did better on the bread, cereal, and grain group questions, $70.5 \%$ knew that one slice of bread, $1 / 2$ cup of rice, and $3 / 4$ cup of cold cereal was the correct serving size. However, only $9.4 \%$ answered correctly that $1 / 2$ cup of green beans was a correct serving size for the vegetables group. Forty-six percent answered correctly that one piece of fruit was a serving size for the fruit group. Thirtyfive percent knew that eight ounces of milk is a serving size for the dairy group. Even though, athletes are taught food groups, number of servings, healthful food selection, and dietary 
guidelines by the $9^{\text {th }}$ grade, ${ }^{1}$ many of the participants do not know what a serving size is. A possible reason why many of the participants did not know what a serving size is for the five food groups is that the portion size of ready to eat foods, at many fast food restaurants, or sitdown restaurants have all gone up two to five times the original size. ${ }^{23}$

Athletes need to have a good diet and be properly hydrated for practices and competitions. The participants did well on the diet section but answered less than two questions correctly on average. The participants were split on whether or not athletes should rely on thirst for proper fluid replacement during practices and competitions. Also, 59\% of the athletes incorrectly believe that Gatorade is better at replacing fluids than water. The results from this study are different from another study ${ }^{15}$ that found more than $50 \%$ of the 31 football players studied believed that sports drinks are not an appropriate substitute for water to replace fluid losses. ${ }^{15}$ Even though, hydration is often a topic with athletics, some of the athletes may be receiving inaccurate information. 


\section{CONCLUSION}

High school athletes lack proper nutrition knowledge as shown by the results on the questionnaire even though students are receiving nutrition information from reputable sources. The athletes are receiving most of their nutrition information from doctors and athletic trainers but are also receiving information from parents/family, coaches, TV, and magazines. Athletes did well on the diet questions but did not score well on the carbohydrate and protein questions. Athletes do not know the role of carbohydrates in the body. They also do not know what a correct serving size is for each of the five food groups. Athletes need to be educated about the role of carbohydrates, correct serving size for the five food groups, and the importance of proper hydration so they may be better informed about the importance of proper nutrition for participation in athletics. 


\section{REFERENCES}

1. Pennsylvania Academic Standards for Health, Safety, and Physical Education. http://www.pde.state.pa.us/stateboard_ed/lib/stateboard_ed/SandyHealth.pdf. Accessed 01/05/2004

2. Witta BG, Stombaugh IA. Nutritional knowledge, eating practices, and health of adolescent Female runners- A 3-year longitudinal study. Int J Sports Nut 1996;6:414-425.

3. Douglas PD, Douglas JG. Nutrition knowledge and food practices of high school athletes. J Am Diet Assoc. 1984;84(10):1198-1202.

4. Cupisti A, D’Alessandro C, Castrogiovanni S, Barale A, Morelli E. Nutrition knowledge And dietary composition in italian adolescent female athletes and non-athletes. Int J Sports Nut Exerc Metab 2002;12:207-219.

5. Eddy JM, Wang MQ, Perko MA, Bartee RT, Dunn MS, Nagy S. The influence of significant others on attitudes, subjective norms, and intentions regarding dietary supplement use among adolescent athletes. Adolescent. 2001;36(143):583-592.

6. Jacobson, BH, Sobonya C, Ransone J. Nutrition practices and knowledge of college varsity athletes: a follow-up. J Strength Cond Res 2001;15(1):63-68

7. Shifflet B, Timm C, Kahanov. Understanding of athletes' nutritional needs among athletes, coaches, and athletic trainers. Res Quart Exer Sport. 2002;73(3):357-362.

8. Kunkel, ME, Lynne B. Peer nutrition education program to improve nutrition knowledge of female collegiate athletes. J Nut Ed. 2001;33:114-116.

9. Rosenbloom CA. Editor. Sports Nutrition: A guide for the professional working with active people. $3^{\text {rd }}$ Ed. Chicago, Ill. The American Dietetic Association. 1993. 13-106.

10. Williams MH. Nutrition for Health, Fitness, and Sport $5^{\text {th }}$ ed. Boston, MA McGraw-Hill 1999. 212-213, 245, 256, 266-267, 281, 482-493.

11. Whitney EN,Rolfes SR. Understanding Nutrition $8^{\text {th }}$ ed. Boston, MA Wadsworth Publishing 1999.2-21,92-97,125-134,161-171, 419-428.

12. Perron M, Endres J. Knowledge, attitudes, and dietary practices of female athletes. $J$ Am Diet Assoc. 1985;85(5):573-576.

13. Bateson A, Finch P. Do adolescents eat enough calcium? Comm Pract 2002;75(11):428-431

14. Rosenbloom CA, Jonnalagadda SS, Skinner R. Nutrition knowledge of collegiate athletes in a division I national collegiate athletic association institution. J Am Diet Assoc 2002;102(3):418-420. 
15. Jonnalagadda SS, Rosenbloom CA, Skinner R. Dietary practices, attitudes, and physiological status of collegiate freshman football players. J Strength Cond Res 2001;15(4):507-513.

16. Schmalz K. Nutritonal beliefs and practices of adolescent athletes. J School Nurs. 1993;9(2):18-22.

17. Zawila LG, Steib CS, Hoogenboom B. The female collegiate cross-country runner: nutritional knowledge and attitudes. J Athl Train. 2003;38(1):67-74.

18. Reading KJ, McCargar LJ, Marriage BJ. Adolescent and young adult male hockey players: Nutrition knowledge and education. Can J of Diet and Res. 1999;60(3):166-169.

19. Parr RB, Porter MA, Hodgson SC. Nutrition knowledge and practice of coaches, trainers and athletes. Physic Sports med. 1984;12(3):127-138.

20. Barr SI. Nutrition knowledge of female varsity athletes and university students. J Am Diet Assoc. 1987;87(12):1660-1664.

21. Gould KL. The effect of nutrition education and "hands on" food preparation training on 8 division I athletes nutrition knowledge and dietary practices. [Master Thesis] Morgantown, WV: West Virginia University; 2003:69-73.

22. Young LR, Nestle M. Expanding portion sizes in the US marketplace: Implications for nutrition counseling. J Am Diet Ass. 2003;103(2):231-234.

23. Loosli AR, Benson J, Gillien DM, Bourdet K. Nutrition habits and knowledge in competitive adolescent female gymnasts. Phys Sports Med. 1986;14(8):118-120 


\section{APPENDICES}




\section{APPENDIX A}

\section{THE PROBLEM}

\section{Research Question}

The number of heat illness-related deaths in the past few years has sparked an interest in hydration and dietary habits. Many studies have come forth with new information regarding dietary habits and ways to prevent performance deficits due to lack of proper dietary intake. This new information is good, but many high school athletes receive this information from advertisements like Gatorade, other sports drink, or food manufacturers, but not from nutrition literature. High school athletes lack formal nutrition education except for information received in health class. Therefore it appears their only knowledge and understanding of sound nutrition practices comes from advertisements, coaches, and/or fellow athletes. In a study by Witta, ${ }^{2}$ athletes asked and received advice about diet and health, mainly from the coach, but also from parents, doctors, and teammates. ${ }^{2}$ The coaches’ nutrition knowledge may not be the most extensive as Parr et $\mathrm{al}^{19}$ noted in his study, which found that $61 \%$ had no formal education in nutrition. Despite this lack of knowledge, fluid intake was the number one priority for the coaches followed by weight, vitamins, pre-game meals, protein, carbohydrate loading, and minerals. ${ }^{19}$ However, in the Schmalz ${ }^{16}$ study on the eating behaviors and knowledge of high school athletes only 3\% were under the supervision of a coach, school nurse, or physician for “training diets.”" Seven percent made up their own "training diets.” Sixty-one percent of the subjects ate a high-fat lunch and 7\% percent ate "junk" food for lunch. Only $26 \%$ of the subjects actually ate a well-balanced lunch. Fifty-two percent believed that protein supplements helped increase muscle size and $48 \%$ believed protein supplements did not help increase muscle size. ${ }^{16}$ 
High school athletes are receiving nutrition information from advertisements that may not be a reliable source. This lack of proper nutrition knowledge is important because, at this age, they are starting to build lifetime nutrition eating habits. It is important that students become informed consumers through classes and the sports arena. Therefore, my research question is: Do high school athletes acquire proper nutrition knowledge early on?

Experimental Hypothesis

1. High school athletes lack nutrition knowledge as measured by the number of students answering 18 questions or less correctly on the questionnaire.

2. High school athletes' nutrition knowledge will mainly come from media sources such as TV and magazines, friends/teammates, and parents/family.

3. There will be a statistical significance between year in school as measured by the score on the nutrition knowledge questionnaire.

4. There will be a statistical significance between gender as measured by the score on the nutrition knowledge questionnaire.

5. There will be a statistical significance between primary sports as measured by the score on the nutrition knowledge questionnaire.

Assumptions

1. The athletes will complete the nutrition questionnaire to the best of their ability.

2. The athletes will be honest when answering the questionnaire.

3. The questionnaire is an appropriate tool to test nutrition knowledge.

Delimitations

1. This study was conducted at one high school in a rural area using 139 athletes in the sports of football, soccer, volleyball, cross country, golf, cheerleading, basketball, wrestling, baseball, softball, and track. This study does not give an accurate picture of other high school athletes.

2. Many high school athletes in this study play more than one sport. This can lead to a smaller number of participants and not an accurate picture of just one sport. 


\section{Operational Definitions}

1. American Dietetic Association (ADA) - professional organization of dietitians in the United States. ${ }^{11}$

2. Amino acids - the main structural material of protein. ${ }^{10}$

3. Anemia - A condition where there are too few red blood cells or immature red blood cells in the blood so the red blood cells have trouble carrying a normal amount of oxygen to the tissues in the body. ${ }^{11}$

4. Branch chain amino acids - three essential amino acids that help to build muscle. ${ }^{10}$

5. Caffeine - a natural stimulant found in foods like chocolate, coffee, tea, and soda. It may help stimulate fatty acid release but causes fluid losses. ${ }^{11}$

6. Calcium - most abundant mineral in the body primarily found in the teeth and bones. ${ }^{11}$

7. Calorie - unit of measurement for energy of food. Food is measured by kilocalories. $(1000 \text { calories }=1 \text { kilocalories })^{11}$

8. Carbohydrates - a group of compounds containing carbon, hydrogen, and oxygen. Glucose is the most well known carbohydrate. ${ }^{10}$

9. Complementary proteins - the combination of two different types of foods to provide a variety of amino acids. ${ }^{10}$

10. Complete protein - protein containing all the essential amino acids. ${ }^{11}$

11. Complex carbohydrates - Foods high in starch such as bread, cereals, fruit and vegetables. $^{10}$

12. Daily Values (DV) - reference values developed by the FDA specifically for use on food labels. ${ }^{11}$

13. Dehydration - reductions of body water below normal levels. ${ }^{10}$

14. Diet - the foods and beverages a person eats and drinks in a day or week. ${ }^{11}$

15. Dietary Reference Intakes (DRI) - a set of values for the dietary nutrition intakes of people in the United States and Canada. ${ }^{11}$

16. Dietitian - a person trained in nutrition, food science, and diet planning. ${ }^{11}$

17. Electrolytes - Substances are found in the cells of the body and the movement of electrolytes initiates a variety of actions. Examples are sodium and potassium. ${ }^{10}$ 
18. Essential amino acids - amino acids the body cannot make in enough amounts to meet the bodies needs to maintain life. ${ }^{11}$

19. Essential fatty acids - fatty acids needed by the body but the body cannot make these in enough amounts to meet the bodies needs. ${ }^{11}$

20. Essential nutrients - nutrients a person must consume from food because the body cannot make them to meet the needs of the body. ${ }^{11}$

21. Fats - lipids in foods or the body that are made up of triglycerides and a 3 fatty acid chain. $^{11}$

22. Fatty acids - an organic compounds composed of a carbon chain with hydrogens attached to it and an acid group at one-end. ${ }^{11}$

23. Food Guide Pyramid - a group approach to healthful nutrition containing five food groups- bread, cereal, rice, and pasta; fruits; vegetables; meat, poultry, fish, dry beans, eggs, nuts; milk, yogurt, and cheese; and fats, oils, sweets (not an official food group). ${ }^{10}$

24. Fluid and electrolyte balance - maintenance of the proper amounts of fluid and electrolytes in the body. ${ }^{11}$

25. Fortified - adding nutrients to food when the food has none or small amounts of a certain nutrient to improve the nutritional value of the food. ${ }^{11}$

26. Fructose - a monosaccaride found in fruits, honey, and saps. ${ }^{11}$

27. Glucose - a mononsaccaride, sometimes known as blood sugar. ${ }^{11}$

28. Glycogen - a substance made and stored in the liver and muscles which can be turned into glucose for energy. ${ }^{11}$

29. Macrominerals - minerals that are essential for the body to function normally and have a RDA above $100 \mathrm{mg} /$ day. Examples include calcium, magnesium, phosphorous, sodium, potassium, and chloride. ${ }^{10}$

30. Macronutrients - nutrients that are needed in large amounts daily to maintain normal functions of the body. This includes carbohydrates, fats, proteins, and water. ${ }^{10}$

31. Metabolism - the sum total of all the chemical reactions that go on in living cells. ${ }^{11}$

32. Micronutrient - nutrient that is needed in only a few grams a day such as vitamins or minerals. ${ }^{10}$

33. Mineral - provides the body with many nutrients like calcium, sodium, and potassium, which are essential to the body. ${ }^{10}$ 
34. Monosaccaride - a simple carbohydrate. ${ }^{11}$

35. Monounsaturated fatty acid - a fatty acid that lacks two hydrogen atoms and has one double bond between carbons. ${ }^{11}$

36. Nonessential nutrient - nutrient that may be formed by the body from other nutrients in the body. ${ }^{10}$

37. Nonessential amino acid - an amino acid that may be formed by the body from other amino acids. $^{10}$

38. Nutrients - chemical substances obtained from food and used in the body to provide energy, growth, maintenance, and tissue repair. ${ }^{11}$

39. Nutrition - the science of foods, nutrients, and other substances contained in food, and their actions within the body. ${ }^{11}$

40. Polysaccharide - many monosaccharides linked together. ${ }^{11}$

41. Potassium - main electrolyte in the cell that is important for fluid balance, nerve transmission, and muscle contractions. ${ }^{11}$

42. Proteins - compounds composed of carbon, hydrogen, oxygen, and nitrogen atoms arranged into amino acids linked in a chain. ${ }^{11}$

43. Recommended Daily Allowance (RDA) - the average daily amount of a nutrient considered adequate to meet the known nutrient needs of most healthy people. ${ }^{11}$

44. Registered Dietitian (RD) - an individual who had graduated with a degree in dietetics or nutrition that is accredited by the American Dietetic Association, completed an internship, passed the registration examination, and maintains continuing education. ${ }^{11}$

45. Rural: an area of that is not heavily populated. ${ }^{24}$

46. Triglycerides - the chief form of fat in the diet and the major storage form of fat in the body. $^{11}$

47. Unsaturated fatty acid - a fatty acid that lacks hydrogen atoms and has at least one double bond between carbons. ${ }^{11}$

48. Vitamins - essential nutrients required in small amounts by the body. ${ }^{11}$

49. Whole-grain - a grain that is not refined and that is milled in its entirety. ${ }^{11}$ 


\section{Limitations}

1. Athletes may not completely fill questionnaire out or be honest when answering the questions.

Significance of the Study

High school athletes lack proper nutrition knowledge. It has been noted in the literature that lack of fluids and inadequate diet can hinder performance. Many high school athletes believe that Gatorade is the most important ingredient in a good diet. While Gatorade is good to help with dehydration and replenish carbohydrates lost during exercise, Gatorade lacks many other important nutrients that are essential for the athlete. High school athletes' dietary habits are formed by those around them such as parents, fellow athletes, and environment. Therefore, the intent of this study was to determine the extent of nutrition knowledge of high school athletes. If their knowledge is low, this will provide evidence to stress that more nutrition education needs to be addressed continually with high school athletes not only in formal health classes but re-iterated by athletic trainers, coaches, and parents. This may lead to the development of sound nutrition practices. Understanding where nutrition knowledge is lacking from this study, may provide insight into how to better educate and inform the athletes, parents, and coaches about addressing proper lifetime eating habits for all involved. 


\section{APPENDIX B}

\section{LITERATURE REVIEW}

Introduction

Eating habits are formed in the home at an early age and later modified or enhanced while attending school. The National School Lunch Act of 1946 states that schools must provide children with nutritious lunches at a free of charge or at a reduced rate. ${ }^{25}$ The lunches must include one or more servings from every food group. There are other school programs such as the National School Breakfast and Afterschool Snack program that help children receive proper nutritious foods for free or at a reduced price. ${ }^{25}$ However, many students do not choose those healthy meals, but instead bring a lunch from home or decide to grab some snack out of the vending machine, that can be high in calories, or loaded with sugar and fat. ${ }^{16}$ Besides providing nutritious meals, many schools around the country require their students to take a health class in high school with nutrition as one of the topics. Even though adolescents are being taught about sound nutrition practices, many are not following this advice. The problem is that many of these unhealthy nutrition practices are being followed by student-athletes, who need to eat the proper amount of food to meet energy demands, prevent injury, repair muscle damage, and support overall health. The literature review will look at general nutrition knowledge, guidelines and position statements, nutrition knowledge of athletes, nutrition sources, nutrition knowledge and attitudes of coaches, athletic trainers, and physical education teachers.

General Nutrition Information

The food guide pyramid recommends everyone should consume 6-11 servings every day from the grain group such as cereal, bread, and pasta. An example of 1 serving from the grain group is 1 slice of bread, 1 ounces of ready-to-eat cereal, and $1 / 2$ cup of cooked rice or pasta. The 
food guide pyramid recommends 3-5 servings daily from the vegetable group. One-cup raw leafy vegetables, $1 / 2$ cup of other vegetables, cooked or chopped raw, 3/4 cup of vegetable juice is an example of 1 serving from the vegetable group. The food guide pyramid recommends 2-4 servings daily from the fruit group. One medium size apple, banana, or orange, $1 / 2$ cup of chopped, cooked, or canned fruit, and 3/4 cup of fruit juice are the recommended serving sizes for the fruit group. The food guide pyramid recommends 2-3 servings from the milk or dairy group daily. A serving size is 1 cup milk or yogurt, 1-1/2 ounces natural cheese, or 2 ounces process cheese. The food guide pyramid recommends 2-3 servings from the meat or protein group daily. An example of a serving size from this group is 2-3 ounces of cooked lean meat, poultry, or fish, $1 / 2$ cup cooked dry beans, or 3 egg counts. ${ }^{10,11,26,27}$

Carbohydrates: Carbohydrates are the main energy source for the body. Simple carbohydrates are made up of either glucose, fructose, or galactose. Complex carbohydrates are made up of many simple carbohydrates combined..$^{10,11,27}$ Complex carbohydrates include glycogen, starches, and fibers. ${ }^{10,11}$ Carbohydrates are broken down into glucose in the body, and then are made into glycogen, which is a stored form of glucose in the liver and muscles. During exercise, the muscles use the glycogen for energy and to keep the blood glucose levels at normal levels so other parts of the body, such as the brain and organs can also use the glucose for energy. Therefore, athletes need a diet high in carbohydrates. ${ }^{10,11,27,28}$ Athletes' diet should be high in complex carbohydrates. A pre-game/event meal should be eaten 3-4 hours before a game and should be high in complex carbohydrates but not high in dietary fiber. ${ }^{10,11,27,28,29}$

Fat: Fat in the diet is important for daily functioning of the body. Fat is important in the diet for energy, hormones, cushioning organs, insulation to keep the body warm, and building cell structures. Fat is also known as lipid, which is broken down into triglycerides, phospholipids, and sterols. Triglycerides are further broken down into three fatty acids and a 
glycerol. Fatty acid can either be unsaturated or saturated. Unsaturated fatty acid is a fatty acid that lacks a hydrogen atom and has at least one double bond between carbons. A saturated fatty acid is a fatty acid that is carrying the maximum number of hydrogen atoms. When foods are processed or packaged for sale, some companies will add hydrogen molecules known as hydrogenation to change the unsaturated fatty acid into or closer to a saturated fatty acid to increase the shelf life of the food. There are two essential fatty acids: linoleic acid (Omega -6) and linolenic acid (Omega -3). Linoleic acid is found in vegetable oils and meats, where linolenic acid is essential for growth and development respectively. They may also help prevent and treat heart disease, hypertension, arthritis, and cancer. Linolenic acid can be found in nuts, seeds, vegetables, fats, and oils. Phospholipids make up the cell membrane and are important for allowing important fat-soluble vitamins and hormones to go in and out of the cell. Food sources of phospholipids are eggs, liver, soybeans, wheat germ, and peanuts. Sex hormones, bile acids, adrenal hormones, cholesterol, and vitamin D are sterols. Sterols are found in meats, eggs, fish, poultry, and dairy products. ${ }^{10,11}$

Protein: Proteins are broken down into amino acids by the body. There are 20 amino acids, some are essential and others are non-essential. Essential amino acids are ones that the body cannot make so they must be supplied by the food. Nonessential amino acids can be made in the body from other sources. Protein is an important building materials for cells, tissues, organs, and enzymes that are important for digestion, daily bodily functions, hormones, regulators of fluid and electrolyte balance, acid-base regulators to keep the body working at the proper $\mathrm{pH}$, transports of nutrients such as oxygen, vitamins and minerals, and antibodies to protect against diseases. ${ }^{10,11}$

Vitamins and minerals: Vitamins and minerals are important for a variety of functions such as coezymes for fat and protein, carbohydrate metabolism, formation of cells, protection 
against cancer, formation of bone, and nerve conduction impulses. Vitamins can be broken down into two categories; fat-soluble and water-soluble. Minerals are broken down into major and trace minerals. ${ }^{10,11}$ Vitamin and minerals names, recommended doses, sources, functions, symptoms of deficiency and excess are listed in Table B1-B4. ${ }^{10}$

Table B1. Fat Soluble Vitamins ${ }^{10}$

\begin{tabular}{|c|c|c|c|c|c|}
\hline Vitamin & $\begin{array}{l}\text { RDA or } \\
\text { equivalent }\end{array}$ & Major Sources & $\begin{array}{l}\text { Major functions in the } \\
\text { body }\end{array}$ & $\begin{array}{l}\text { Deficiency } \\
\text { symptoms }\end{array}$ & $\begin{array}{l}\text { Symptoms of } \\
\text { excess }\end{array}$ \\
\hline $\begin{array}{l}\text { Vitamin A } \\
\text { (Retinol; } \\
\text { provitamin } \\
\text { carotenoids }\end{array}$ & $\begin{array}{l}\text { Males age } \\
\text { 11-18: } \\
\text { 1,000 ug } \\
\text { Females } \\
\text { age 11-18: } \\
800 \text { ug }\end{array}$ & $\begin{array}{l}\text { Liver, whole } \\
\text { milk, fortified } \\
\text { milk, cheese, } \\
\text { carrots, green } \\
\text { leafy } \\
\text { vegetables, } \\
\text { sweet potatoes }\end{array}$ & $\begin{array}{l}\text { Maintains epithelial } \\
\text { tissue in skin and } \\
\text { mucous membranes, } \\
\text { forms visual purple for } \\
\text { night vision, promotes } \\
\text { bone development }\end{array}$ & $\begin{array}{l}\text { Night blindness, } \\
\text { intestinal } \\
\text { infections, } \\
\text { impaired growth }\end{array}$ & $\begin{array}{l}\text { Nausea, } \\
\text { headache, } \\
\text { fatigue, liver and } \\
\text { spleen damage, } \\
\text { skin peeling, } \\
\text { pain in joints }\end{array}$ \\
\hline $\begin{array}{l}\text { Vitamin D } \\
\text { (cholecalciferol) }\end{array}$ & $\begin{array}{l}\text { Males and } \\
\text { Females } \\
\text { ages 11-18: } \\
10 \text { ug }\end{array}$ & $\begin{array}{l}\text { Vitamin D } \\
\text { fortified foods } \\
\text { like dairy } \\
\text { products and } \\
\text { margarine, fish } \\
\text { oils, action of } \\
\text { sunlight on the } \\
\text { skin }\end{array}$ & $\begin{array}{l}\text { Acts as a hormone to } \\
\text { increase intestinal } \\
\text { absorption of calcium } \\
\text { and promote bone and } \\
\text { tooth formation }\end{array}$ & $\begin{array}{l}\text { Rare. Rickets in } \\
\text { children and } \\
\text { osteomalacia in } \\
\text { adults }\end{array}$ & $\begin{array}{l}\text { Loss of appetite, } \\
\text { nausea, } \\
\text { irritability, joint } \\
\text { pain, calcium } \\
\text { deposits in soft } \\
\text { tissues }\end{array}$ \\
\hline Vitamin E & $\begin{array}{l}\text { Males ages } \\
\text { 11-18: } 10 \\
\text { ug, } \\
\text { Females } \\
\text { ages 11- } \\
\text { 18: } 8 \text { ug }\end{array}$ & $\begin{array}{l}\text { Vegetable oils, } \\
\text { margarine, } \\
\text { green leafy } \\
\text { vegetables, } \\
\text { wheat germ, } \\
\text { whole grain } \\
\text { products, egg } \\
\text { yolks }\end{array}$ & $\begin{array}{l}\text { Functions as an } \\
\text { antioxidant to protect } \\
\text { cell membranes from } \\
\text { destruction by } \\
\text { oxidation }\end{array}$ & $\begin{array}{l}\text { Extremely rare. } \\
\text { Disruption of red } \\
\text { blood cell } \\
\text { membrane, } \\
\text { anemia }\end{array}$ & $\begin{array}{l}\text { General lack of } \\
\text { toxicity with } \\
\text { doses up to } 400 \\
\text { mg. Some } \\
\text { reports of } \\
\text { headache, } \\
\text { fatigue, or } \\
\text { diarrhea with } \\
\text { megadoses }\end{array}$ \\
\hline $\begin{array}{l}\text { Vitamin K } \\
\text { (phylloquinone, } \\
\text { menoquinone) }\end{array}$ & $\begin{array}{l}\text { Males ages } \\
\text { 11-14: } 45 \\
\text { ug, Males } \\
\text { ages 15-18: } \\
65 \text { ug, } \\
\text { Females } \\
\text { ages 11- } \\
\text { 14: } 45 \text { ug, } \\
\text { Females } \\
\text { ages 15-18: } \\
55 \text { ug }\end{array}$ & $\begin{array}{l}\text { Pork and beef } \\
\text { liver, eggs, } \\
\text { spinach, } \\
\text { cauliflower }\end{array}$ & $\begin{array}{l}\text { Essential for blood } \\
\text { coagulation processes }\end{array}$ & $\begin{array}{l}\text { Increase } \\
\text { bleeding and } \\
\text { hemorrhage }\end{array}$ & $\begin{array}{l}\text { Possible clot } \\
\text { formation } \\
\text { (thrombosis), } \\
\text { vomiting }\end{array}$ \\
\hline
\end{tabular}


TABLE B2. Water Soluble Vitamins ${ }^{10}$

\begin{tabular}{|c|c|c|c|c|c|}
\hline Vitamin & $\begin{array}{l}\text { RDA or } \\
\text { equivalent }\end{array}$ & Major sources & $\begin{array}{l}\text { Major functions in } \\
\text { the body }\end{array}$ & $\begin{array}{l}\text { Deficiency } \\
\text { symptoms }\end{array}$ & $\begin{array}{l}\text { Symptoms of } \\
\text { excess }\end{array}$ \\
\hline $\begin{array}{l}\text { Thiamin } \\
\text { (vitamin } B_{1} \text { ) }\end{array}$ & $\begin{array}{l}\text { Males ages 11- } \\
\text { 14: } 1.3 \mathrm{mg}, \\
\text { Males ages } 15- \\
\text { 18: } 1.5 \mathrm{mg} \\
\\
\text { Females ages } \\
11-18: 1.1 \mathrm{mg}\end{array}$ & $\begin{array}{l}\text { Ham, pork, } \\
\text { lean meat, } \\
\text { whole-grain } \\
\text { products, } \\
\text { enriched } \\
\text { breads, and } \\
\text { cereals, } \\
\text { legumes }\end{array}$ & $\begin{array}{l}\text { Serves as coenzymes } \\
\text { for energy production } \\
\text { from carbohydrates; } \\
\text { essential for normal } \\
\text { functioning of the } \\
\text { central nervous } \\
\text { system }\end{array}$ & $\begin{array}{l}\text { Poor appetite, } \\
\text { apathy, mental } \\
\text { depression, } \\
\text { pain in calf } \\
\text { muscles }\end{array}$ & None \\
\hline $\begin{array}{l}\text { Riboflavin } \\
\text { (vitamin } \mathrm{B}_{2} \text { ) }\end{array}$ & $\begin{array}{l}\text { Males ages 11- } \\
\text { 14: } 15 \mathrm{mg}, \\
\text { Males ages 15- } \\
\text { 18: } 1.8 \mathrm{mg} \\
\text { Females ages } \\
\text { 11-18: } 1.3 \mathrm{mg}\end{array}$ & $\begin{array}{l}\text { Milk and dairy } \\
\text { products, meat, } \\
\text { enriched grain } \\
\text { products, green } \\
\text { leafy } \\
\text { vegetables, } \\
\text { beans }\end{array}$ & $\begin{array}{l}\text { Functions as a } \\
\text { coenzymes involved } \\
\text { in energy production } \\
\text { from carbohydrates } \\
\text { and fats, maintenance } \\
\text { of healthy skin }\end{array}$ & $\begin{array}{l}\text { Dermatitis, } \\
\text { cracks at the } \\
\text { corners of } \\
\text { mouth, sores } \\
\text { on the tongue, } \\
\text { damage to the } \\
\text { cornea }\end{array}$ & None \\
\hline $\begin{array}{l}\text { Niacin (vitamin } \\
\mathrm{B}_{3} \text { ) }\end{array}$ & $\begin{array}{l}\text { Males ages 11- } \\
\text { 14:17 mg, Males } \\
\text { 15-18: } 20 \mathrm{mg} \\
\text { Females ages } \\
\text { 11-18: } 15 \mathrm{mg}\end{array}$ & $\begin{array}{l}\text { Lean meats, } \\
\text { fish, poultry, } \\
\text { whole-grain } \\
\text { products, beans }\end{array}$ & $\begin{array}{l}\text { Functions as a } \\
\text { coenzyme for the } \\
\text { aerobic and anaerobic } \\
\text { production of energy } \\
\text { from carbohydrate, } \\
\text { helps synthesize fat } \\
\text { and blocks release of } \\
\text { free fatty acid, } \\
\text { needed for health } \\
\text { skin }\end{array}$ & $\begin{array}{l}\text { Loss of } \\
\text { appetite, } \\
\text { weakness, skin } \\
\text { lesions, } \\
\text { gastrointestinal } \\
\text { problems }\end{array}$ & $\begin{array}{l}\text { Headache, } \\
\text { nausea, } \\
\text { burning and } \\
\text { itching skin, } \\
\text { flushing of } \\
\text { face, liver } \\
\text { damage }\end{array}$ \\
\hline Vitamin $\mathrm{B}_{6}$ & $\begin{array}{l}\text { Males ages 11- } \\
\text { 14: } 1.7 \mathrm{mg}, \\
\text { Males ages 15- } \\
\text { 18: } 2 \mathrm{mg} \\
\\
\text { Females ages } \\
\text { 11-14: } 1.4 \mathrm{mg} \\
\text { Females ages } \\
\text { 15-18: } 1.5 \mathrm{mg}\end{array}$ & $\begin{array}{l}\text { Protein foods, } \\
\text { liver meats, } \\
\text { fish, poultry, } \\
\text { legumes, green } \\
\text { leafy } \\
\text { vegetables }\end{array}$ & $\begin{array}{l}\text { Functions as a } \\
\text { coenzyme in protein } \\
\text { metabolism, } \\
\text { necessary for } \\
\text { formation of } \\
\text { hemoglobin and red } \\
\text { blood cells, needed } \\
\text { for glycogenolysis } \\
\text { and glyconeogensis }\end{array}$ & $\begin{array}{l}\text { Nervous } \\
\text { irritability, } \\
\text { convulsions, } \\
\text { dermatitis, } \\
\text { sores of } \\
\text { tongues, } \\
\text { anemia }\end{array}$ & $\begin{array}{l}\text { Loss of nerve } \\
\text { sensation, } \\
\text { impaired gait }\end{array}$ \\
\hline Vitamin $B_{12}$ & $\begin{array}{l}\text { Males and } \\
\text { Females ages } \\
\text { 11-18: } 2 \text { ug }\end{array}$ & $\begin{array}{l}\text { Meat, fish, } \\
\text { poultry, milk, } \\
\text { eggs }\end{array}$ & $\begin{array}{l}\text { Functions as a } \\
\text { coenzyme for } \\
\text { formation of DNA, } \\
\text { red blood cell } \\
\text { development, and } \\
\text { maintenance of nerve } \\
\text { tissue }\end{array}$ & $\begin{array}{l}\text { Pernicious } \\
\text { anemia, nerve } \\
\text { damage } \\
\text { resulting in } \\
\text { paralysis }\end{array}$ & None \\
\hline
\end{tabular}




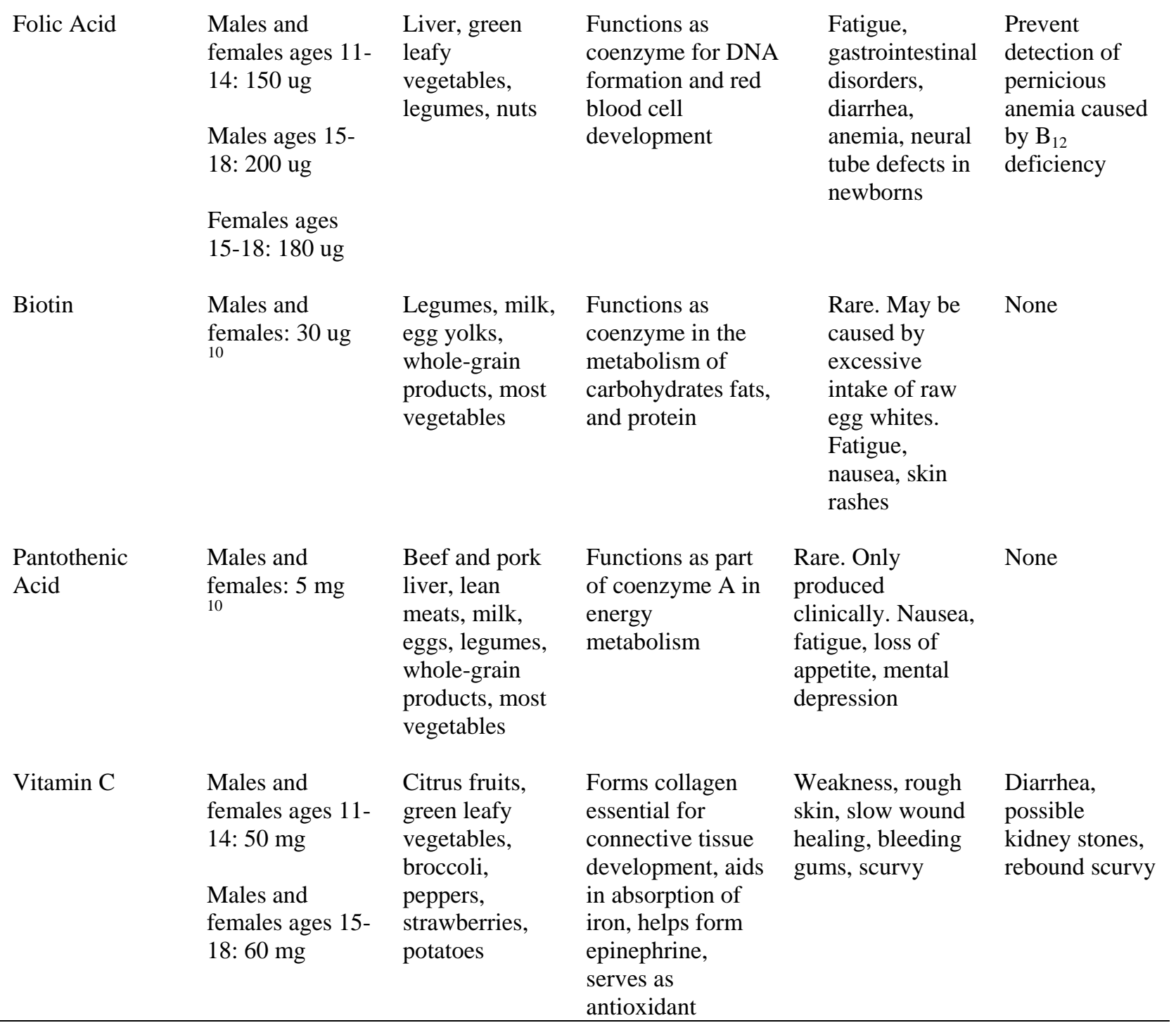


Table B3. Major Minerals ${ }^{10}$

\begin{tabular}{|c|c|c|c|c|c|}
\hline Mineral & $\begin{array}{l}\text { RDA or } \\
\text { equivalent }\end{array}$ & $\begin{array}{l}\text { Major food } \\
\text { sources }\end{array}$ & $\begin{array}{l}\text { Major functions in } \\
\text { the body }\end{array}$ & $\begin{array}{l}\text { Deficiency } \\
\text { symptoms }\end{array}$ & $\begin{array}{l}\text { Symptoms of } \\
\text { excess }\end{array}$ \\
\hline Calcium (Ca) & $\begin{array}{l}\text { Males and } \\
\text { females } \\
\text { ages } 11- \\
\text { 18: } 1,200 \\
\text { mg }\end{array}$ & $\begin{array}{l}\text { Milk, cheese, ice } \\
\text { cream, yogurt, } \\
\text { egg yolks, dried } \\
\text { beans and peas, } \\
\text { dark-green leafy } \\
\text { vegetables, } \\
\text { cauliflower }\end{array}$ & $\begin{array}{l}\text { Bone formation, } \\
\text { enzyme activation, } \\
\text { nerve impulse } \\
\text { transmission, muscle } \\
\text { contraction, cell } \\
\text { membrane }\end{array}$ & $\begin{array}{l}\text { Osteoporosis, } \\
\text { rickets, } \\
\text { impaired muscle } \\
\text { contraction, } \\
\text { muscle cramps }\end{array}$ & $\begin{array}{l}\text { Constipation, } \\
\text { inhibition of } \\
\text { trace mineral } \\
\text { absorption, in } \\
\text { susceptible } \\
\text { individuals, heart } \\
\text { arrhythmias, } \\
\text { kidney stones, } \\
\text { calcification of } \\
\text { soft tissues }\end{array}$ \\
\hline Phosphorus (P) & $\begin{array}{l}\text { Males and } \\
\text { females } \\
\text { ages } 11- \\
\text { 18: } 1,200 \\
\text { mg }\end{array}$ & $\begin{array}{l}\text { All protein } \\
\text { products, meat, } \\
\text { poultry, fish, } \\
\text { eggs, milk, } \\
\text { cheese, dried } \\
\text { beans and peas, } \\
\text { whole-grain } \\
\text { products, soft } \\
\text { drinks }\end{array}$ & $\begin{array}{l}\text { Bone formation, } \\
\text { acid-base balance, } \\
\text { cell membrane } \\
\text { structure, B vitamin } \\
\text { activation, organic } \\
\text { compound } \\
\text { component }\end{array}$ & $\begin{array}{l}\text { Rare, muscular } \\
\text { weakness }\end{array}$ & $\begin{array}{l}\text { Rare, impaired } \\
\text { calcium } \\
\text { metabolism, } \\
\text { gastrointestinal } \\
\text { distress from } \\
\text { phosphate salts }\end{array}$ \\
\hline $\begin{array}{l}\text { Magnesium } \\
\text { (Mg) }\end{array}$ & $\begin{array}{l}\text { Males ages } \\
\text { 11-14: } 270 \\
\text { mg, ages } \\
\text { 15-18: } 400 \\
\text { mg } \\
\text { Females } \\
\text { ages 11- } \\
\text { 14: } 280 \\
\text { mg, ages } \\
\text { 15-18: } 300 \\
\text { mg }\end{array}$ & $\begin{array}{l}\text { Milk, yogurt, } \\
\text { dried beans, nuts, } \\
\text { whole-grain } \\
\text { products, fruits } \\
\text { and vegetables, } \\
\text { especially green } \\
\text { leafy vegetables }\end{array}$ & $\begin{array}{l}\text { Protein synthesis, } \\
\text { metalloenzyme, 2-3 } \\
\text { DPG formation, } \\
\text { glucose metabolism, } \\
\text { smooth muscle } \\
\text { contraction, bone } \\
\text { component }\end{array}$ & $\begin{array}{l}\text { Rare, muscle } \\
\text { weakness, } \\
\text { apathy, muscle } \\
\text { twitching, } \\
\text { muscle cramps, } \\
\text { cardiac } \\
\text { arrhythmias }\end{array}$ & $\begin{array}{l}\text { Nausea, } \\
\text { vomiting, } \\
\text { diarrhea }\end{array}$ \\
\hline
\end{tabular}

Table B4. Minor Minerals ${ }^{10}$

\begin{tabular}{|c|c|c|c|c|c|}
\hline Mineral & $\begin{array}{l}\text { RDA or } \\
\text { equivalent }\end{array}$ & $\begin{array}{l}\text { Major food } \\
\text { sources }\end{array}$ & $\begin{array}{l}\text { Major functions in } \\
\text { the body }\end{array}$ & $\begin{array}{l}\text { Deficiency } \\
\text { symptoms }\end{array}$ & $\begin{array}{l}\text { Symptoms of } \\
\text { excess }\end{array}$ \\
\hline Iron $(\mathrm{Fe})$ & $\begin{array}{l}\text { Males ages 11- } \\
\text { 18: } 12 \mathrm{mg} \\
\text { Females ages } \\
\text { 11-18: } 15 \mathrm{mg}\end{array}$ & $\begin{array}{l}\text { Liver, meat, fish, } \\
\text { poultry, shellfish } \\
\text { (mainly oysters), } \\
\text { dried beans and } \\
\text { peas, whole- } \\
\text { grain products, } \\
\text { green leafy } \\
\text { vegetables, } \\
\text { spinach, } \\
\text { broccoli, dried } \\
\text { apricots, dates, } \\
\text { figs, raisins }\end{array}$ & $\begin{array}{l}\text { Hemoglobin and } \\
\text { myoglobin } \\
\text { formation, } \\
\text { electron transfer, } \\
\text { essential in } \\
\text { oxidative process }\end{array}$ & $\begin{array}{l}\text { Fatigue, } \\
\text { anemia, } \\
\text { impaired } \\
\text { temperature } \\
\text { regulation, } \\
\text { decreased } \\
\text { resistance to } \\
\text { infection }\end{array}$ & $\begin{array}{l}\text { Hemochromatosis, } \\
\text { liver damage }\end{array}$ \\
\hline
\end{tabular}




\begin{tabular}{|c|c|c|c|c|c|}
\hline Copper (Cu) & $\begin{array}{l}\text { Males and } \\
\text { Females: } 1.5-3 \\
\text { mg }^{11}\end{array}$ & $\begin{array}{l}\text { Liver, meat, fish, } \\
\text { poultry, } \\
\text { shellfish, nuts, } \\
\text { eggs, bran } \\
\text { cereals, avocado, } \\
\text { broccoli, banana }\end{array}$ & $\begin{array}{l}\text { Proper use of iron } \\
\text { and hemoglobin } \\
\text { in the body, } \\
\text { metalloenzyme } \\
\text { involved in } \\
\text { connective tissue } \\
\text { formation and } \\
\text { oxidations }\end{array}$ & Rare, anemia & $\begin{array}{l}\text { Rare, nausea and } \\
\text { vomiting }\end{array}$ \\
\hline Zinc (Zn) & $\begin{array}{l}\text { Males ages 11- } \\
\text { 18:15 mg } \\
\text { Females ages } \\
\text { 11-18: } 12 \mathrm{mg}\end{array}$ & $\begin{array}{l}\text { Organ meats, } \\
\text { meat, fish, } \\
\text { poultry, shellfish } \\
\text { mainly oysters, } \\
\text { daily products, } \\
\text { nuts, whole- } \\
\text { grain products, } \\
\text { vegetables, } \\
\text { asparagus, } \\
\text { spinach }\end{array}$ & $\begin{array}{l}\text { Cofactor of many } \\
\text { enzymes involved } \\
\text { in energy } \\
\text { metabolism, } \\
\text { protein synthesis, } \\
\text { immune function, } \\
\text { sexual maturation } \\
\text { and sensations of } \\
\text { taste and smell }\end{array}$ & $\begin{array}{l}\text { Depressed } \\
\text { immune } \\
\text { function, } \\
\text { impaired } \\
\text { would } \\
\text { healing, } \\
\text { depressed } \\
\text { appetite, } \\
\text { failure to } \\
\text { grow } \\
\text { properly, skin } \\
\text { inflammation }\end{array}$ & $\begin{array}{l}\text { Increase LDL and } \\
\text { decreased HDL, } \\
\text { cholesterol, } \\
\text { impaired immune } \\
\text { system, nausea, } \\
\text { vomiting, inhibits } \\
\text { copper absorption }\end{array}$ \\
\hline Chromium (Cr) & $\begin{array}{l}\text { Males and } \\
\text { Females: 5-200 } \\
\text { ug }^{11}\end{array}$ & $\begin{array}{l}\text { Organ meats } \\
\text { such as liver, } \\
\text { meats, oysters, } \\
\text { cheese, whole- } \\
\text { grain products, } \\
\text { asparagus, beer }\end{array}$ & $\begin{array}{l}\text { Enhances insulin } \\
\text { function as } \\
\text { glucose tolerance } \\
\text { factor }\end{array}$ & $\begin{array}{l}\text { Glucose } \\
\text { intolerance, } \\
\text { impaired lipid } \\
\text { metabolism }\end{array}$ & $\begin{array}{l}\text { Rare from dietary } \\
\text { sources }\end{array}$ \\
\hline Selenium (Se) & $\begin{array}{l}\text { Males: } 70 \text { ug } \\
\text { Females: } 55 \text { ug }^{11}\end{array}$ & $\begin{array}{l}\text { Meat, fish, } \\
\text { poultry, organ } \\
\text { meats such as } \\
\text { liver, kidney, } \\
\text { seafood, whole } \\
\text { grains and nuts } \\
\text { from selenium } \\
\text { rich soil }\end{array}$ & $\begin{array}{l}\text { Cofactor of } \\
\text { glutathione } \\
\text { peroxidase and } \\
\text { antioxidant } \\
\text { enzyme }\end{array}$ & $\begin{array}{l}\text { Rare, cardiac } \\
\text { muscle } \\
\text { damage }\end{array}$ & $\begin{array}{l}\text { Nausea, vomiting } \\
\text { abdominal pain, } \\
\text { hair loss }\end{array}$ \\
\hline Cobalt (Co) & $\begin{array}{l}\text { No } \\
\text { recommendation } \\
\text { has been } \\
\text { established }\end{array}$ & Meat, liver, milk & $\begin{array}{l}\text { Component of } \\
\text { vitamin } \mathrm{B}_{12} \\
\text { promotes } \\
\text { development of } \\
\text { red blood cells }\end{array}$ & None & $\begin{array}{l}\text { Nausea, vomiting } \\
\text { death }\end{array}$ \\
\hline Fluoride (F) & $\begin{array}{l}\text { Males: } 3.8 \mathrm{mg} \\
\text { Females: } 3.1 \mathrm{mg} \\
11\end{array}$ & $\begin{array}{l}\text { Milk, eggs } \\
\text { yolks, drinking } \\
\text { water, seafood }\end{array}$ & $\begin{array}{l}\text { Helps form bones } \\
\text { and teeth }\end{array}$ & $\begin{array}{l}\text { Higher } \\
\text { incidence of } \\
\text { dental } \\
\text { cavities }\end{array}$ & Discolored teeth \\
\hline
\end{tabular}




$\begin{array}{llllll}\text { Manganese (Mn) } & \begin{array}{l}\text { Males and } \\ \text { Females: 2-5 mg } \\ 11\end{array} & \begin{array}{l}\text { Whole-grain } \\ \text { products, dried } \\ \text { peas and beans, } \\ \text { leafy vegetables, } \\ \text { bananas }\end{array} & \begin{array}{l}\text { Many enzymes } \\ \text { involved in } \\ \text { energy } \\ \text { metabolism, bone } \\ \text { formation, fat } \\ \text { synthesis }\end{array} & \text { None } & \text { Rare } \\ \begin{array}{l}\text { Molybdenum } \\ \text { (Mo) }\end{array} & \begin{array}{l}\text { Males and } \\ \text { Females: } 75-250 \\ \text { ug }^{11}\end{array} & \begin{array}{l}\text { Liver, organ } \\ \text { meats, whole- } \\ \text { grain products, } \\ \text { dried beans and } \\ \text { peas }\end{array} & \begin{array}{l}\text { Works with } \\ \text { riboflavin in } \\ \text { enzymes involved } \\ \text { in carbohydrate } \\ \text { and fat } \\ \text { metabolism }\end{array} & \text { None } & \text { Rare } \\ & & & & \\ & & & \end{array}$

Water and Electrolytes ${ }^{10,11,30,31}$

Water is an essential nutrient for the body. It is important for building material for cell

protoplasma, and protects key body tissues such as the spinal cord and brain. Water controls the osmotic pressure in the body and maintains balance between water and electrolytes. Changes in electrolytes effects cell functioning. It is a main constituent of blood to transport oxygen, nutrients, hormones, and other compounds throughout the body. Water helps to properly maintain the functions of the inner ear and eye. Water also helps to regulate body temperature. ${ }^{10,11}$ Athletes lose large amounts of water during exercise so they need to drink plenty of liquids to replace all lost fluids. Athletes should drink 14-22 ounces of water two hours prior to practice or competition and 7-10 ounces of water 10-20 minutes before exercise.

Athletes should drink 6-12 ounces of water every 15 to 20 minutes during exercise. Athletes need to drink 24 ounces of water for every pound lost during exercise. ${ }^{30,31,32}$ Lack of water leads to dehydration, heat illness, stroke, heart attack, or death. Excess water can lead to hypokalemia. ${ }^{10,31,32}$ The major electrolytes are listed in Table B5. 
Table B5. Major electrolytes ${ }^{10}$

\begin{tabular}{|c|c|c|c|c|}
\hline Electrolyte & $\begin{array}{l}\text { Estimated } \\
\text { minimum } \\
\text { requirement }\end{array}$ & $\begin{array}{l}\text { Major functions in the } \\
\text { body }\end{array}$ & Deficiency symptoms & $\begin{array}{l}\text { Symptoms of } \\
\text { excess }\end{array}$ \\
\hline Sodium (Na) & 500 milligrams & $\begin{array}{l}\text { Primary positive ion } \\
\text { in extracellular fluid, } \\
\text { nerve impulse } \\
\text { conduction, acid-base } \\
\text { balance, blood volume } \\
\text { homeostasis }\end{array}$ & $\begin{array}{l}\text { Hypoatremia, muscle } \\
\text { cramps, nausea, } \\
\text { vomiting, loss of } \\
\text { appetite, dizziness, } \\
\text { seizures, shock, coma }\end{array}$ & Hypertension \\
\hline Chloride (Cl) & 750 milligrams & $\begin{array}{l}\text { Primary negative ion } \\
\text { in extracellular fluid, } \\
\text { nerve conduction, } \\
\text { hydrochloric acid } \\
\text { formation in stomach }\end{array}$ & $\begin{array}{l}\text { Rare, may be caused } \\
\text { by excess vomiting and } \\
\text { loss of hydrochloric } \\
\text { acid, convulsions }\end{array}$ & $\begin{array}{l}\text { Hypertension in } \\
\text { conjunction with } \\
\text { excess sodium }\end{array}$ \\
\hline Potassium (K) & 2,000 milligrams & $\begin{array}{l}\text { Primary positive ion } \\
\text { in intracellular fluid, } \\
\text { same function as } \\
\text { sodium but } \\
\text { intracellular, glucose } \\
\text { transport into cell }\end{array}$ & $\begin{array}{l}\text { Hypokalemia, loss of } \\
\text { appetite, muscle } \\
\text { cramps, apathy, } \\
\text { irregular heartbeat }\end{array}$ & $\begin{array}{l}\text { Hyperkalemia, } \\
\text { inhibited heart } \\
\text { function }\end{array}$ \\
\hline
\end{tabular}

Position Statements and Guidelines

The American Dietetic Association, Dietitians of Canada, and the American College of Sports Medicine position paper on nutrition and athletic performance, states that inadequate food intake during high-intensity training can lead to increased risk of fatigue, injury, or illness, loss of muscle mass, menstrual dysfunction, and loss or failure to gain bone density.,30

Carbohydrates are very important for athletes especially since carbohydrates are the main source of energy for the body. Carbohydrates are stored in the muscles and liver as glycogen., 9,28,29 During exercise when carbohydrates are needed at a much higher level, the body uses the stored glycogen to keep the blood glucose levels at a normal level so the body can function normally. Athletes should consume 7 to 10 grams of carbohydrate/kilogram (kg) per day but athletes who train 4 or more hours a day should consume 12-13 grams of carbohydrate/kg per day. Athletes should consume most of their carbohydrates from complex carbohydrates such as whole-grain bread or cereals because they provide vitamin B, fiber, and iron, which athletes need.,28 
Endurance athletes should consume 1.2 to 1.4 grams of protein per kilogram of body weight per day. ${ }^{9,30}$ Resistance or strength-trained athletes should consume as much as 1.4 to 1.8 grams of protein per kilogram of body weight per day., ${ }^{9,28,30}$ Athletes should not consume more than 2 grams of protein per kilogram of body weight per day because this can cause more strain on the kidneys, cause dehydration, calcium loss, risk of inadequate protein and is of little benefit. ${ }^{9,28}$ Athletes should not be on a low-fat diet because they need fat to help absorb fat-soluble vitamins and for energy. ${ }^{30}$ Fat should account for $20-25 \%$ of the daily caloric intake. ${ }^{29,30}$ Athletes need to consume enough food to meet the minimum guidelines for RDA/DRI for all micronutrients. ${ }^{30}$ Athletes should have a meal or snack 2-3 hours before practice or competition that is low in fat and fiber, high in carbohydrates, easy to digest, and containing some protein. ${ }^{9,27,28,29,30}$ Liquid meals can also be a good pre-game meal because they have a shorter gastric emptying time and are high in carbohydrates. ${ }^{9,28,29}$ They also are good to keep weight gain at a minimal level, especially in wrestlers. Liquid meals are also good for athletes, who are competing in tournaments, long events, or multiple events to help replace lost nutrients, and when the caloric requirements are high. Carbohydrate-rich drinks or foods should be consumed during exercise for events lasting longer than one hour. The athletes should not use any carbohydrate drinks that contain fructose because fructose can cause digestion problems. ${ }^{9,28}$ After exercise, athletes should consume a carbohydrate intake of 1.5 grams per kilogram of body weight 30 minutes after exercise and again every 2 hours for 4-6 hours post exercise to help replenish muscle glycogen, and start to repair muscle damage. ${ }^{9,30}$ Athletes should consume less than $30 \%$ of calories from fat. It is not recommended that athletes be on a low-fat diet. Vitamins and minerals are important for everyone for normal body functions. Vegetarian athletes may need to use B12 supplements. It is important for athletes to consume the DRI for thiamin, riboflavin, and niacin because they help the body digest and use carbohydrates and fat for energy. Vitamin 
E helps to protect the muscle from damage so vitamin E is very important and supplementation may be necessary. ${ }^{9}$ Athletes should always consume the RDA for calcium and may need to increase the amount of calcium when exercising in hot conditions if they have an excessive sweat rate. ${ }^{9,28}$ Over consumption of phosphorus can lead to more fractures so it is important that athletes limit the amount of carbonated beverages because they are loaded with phosphorus. Potassium and sodium are important for cell functioning. The athlete may not need extra potassium or sodium. However, when exercising in hot, humid conditions, athletes need to increase the amount of sodium in their diet. ${ }^{9}$ Iron is an important mineral for athletes, especially females, but supplementation is not necessary except for those athletes who have iron deficiency anemia. $^{9,28}$

Athletes do not need to take any protein, amino acid, vitamin, or mineral supplements as long as the athlete is eating from a variety of food groups. Vegetarian athletes might be at risk for nutritional deficiency so they may need to consult a registered dietitian. ${ }^{30}$ It is important that young female athletes consume enough calcium and iron to prevent bone problems, anemia, and amenorrhea, which can lead to fatigue, hinder performance, and can lead to an increase in the risk of injuries. Athletes should consume many fruits and vegetables, mainly after practice or competition. $^{30}$

Pennsylvania has academic standards for health, safety, and physical education for all students in primary and secondary education. The important education standard for this study is nutrition education. Students in third grade learn about the food guide pyramid in planning a healthy diet as $12^{\text {th }}$ graders learn to analyze factors that impact nutrition choices. ${ }^{1}$ Table B6 lists the academic standards. ${ }^{1}$ 
Table B6. Pennsylvania State Academic Standards ${ }^{1}$

\begin{tabular}{|c|c|c|c|}
\hline Grade 3 & Grade 6 & Grade 9 & Grade 12 \\
\hline $\begin{array}{l}\text { Explain the role of the } \\
\text { food guide pyramid in } \\
\text { helping people eat a } \\
\text { healthy diet. } \\
\text { - } \quad \text { Food groups } \\
\text { - } \quad \text { Number of servings } \\
\text { - } \quad \text { Variety of food } \\
\text { - } \quad \text { Nutrients }\end{array}$ & $\begin{array}{l}\text { Analyze nutrition concepts } \\
\text { that impact health. } \\
\text { - } \quad \text { Caloric content of } \\
\text { foods } \\
\text { - } \quad \text { Relationship of food } \\
\text { intake and physical } \\
\text { activity (energy } \\
\text { output) } \\
\text { - } \quad \text { Nutrient requirements } \\
\text { - } \quad \text { Label reading } \\
\text { - Healthful food } \\
\text { selections }\end{array}$ & $\begin{array}{l}\text { Analyze factors that } \\
\text { impact nutrition choices of } \\
\text { adolescents. } \\
\text { - } \quad \text { Body image } \\
\text { - } \quad \text { Advertising } \\
\text { - } \quad \text { Dietary guidelines } \\
\text { - } \quad \text { Eating disorders } \\
\text { - } \quad \text { Peer influence } \\
\text { - } \quad \text { Athletic goals }\end{array}$ & $\begin{array}{l}\text { Analyze factors that } \\
\text { impact nutrition choices of } \\
\text { adults. } \\
\text { - } \quad \text { Cost } \\
\text { - } \quad \text { Food preparation } \\
\text { (e.g., time, skills) } \\
\text { - Consumer skills (e.g., } \\
\text { understanding food } \\
\text { labels, evaluating } \\
\text { fads) } \\
\text { - Nutrition knowledge } \\
\text { - Changes in nutrition } \\
\text { requirements (e.g., } \\
\text { age, physical activity } \\
\text { level) }\end{array}$ \\
\hline
\end{tabular}

Studies on High School Athletes

In most states, students are required to take a general health class, in which nutrition may or may not be taught as part of the curriculum. Therefore, many high school athletes may not have proper nutrition knowledge. Many adolescents have diets that are inadequate to meet their energy requirements. Perron and Endres ${ }^{12}$ observed the knowledge, attitudes, and dietary practices of female high school volleyball players. They found that $70 \%$ of the athletes did not eat $100 \%$ of their recommended daily allowance (RDA) for calcium and iron but they consumed more than the RDA for vitamin A and C. A majority of the foods consumed were from the “other” group such as candy and sweets. The athletes scored higher on the general nutrition questions than on the nutrition for the athlete questions. In general, the subjects had a positive attitude towards nutrition. ${ }^{12}$ In another study, Cupisti et $\mathrm{al}^{4}$ evaluated the nutrition knowledge and dietary composition of Italian female athletes and non-athletes. They found that the energy intake was the same for both athletes and non-athletes, but both groups did not consume enough food. The athletes' diet were mainly composed of a high intake of carbohydrates and a low intake of fat, when compared to the non-athlete group. Both groups consumed more than $15 \%$ of their dietary intake from protein sources, mainly from meat, ham, and poultry. The athletes 
consumed more than their RDA for iron and vitamin A, when compared to the non-athletes. All groups consumed the RDA for minerals. The athletes consumed more fiber than the nonathletes. Athletes ate a bigger breakfast than the non-athletes. Athletes ate toast, corn flakes, milk, jam, and sugar, whereas the non-athletes consumed more high-fat high sugar snacks and chips than the athletes. The athletes scored higher then the non-athletes on the nutrition knowledge test. Both groups stated that their nutrition knowledge mainly came from family, media, and school. ${ }^{4}$ Douglas and Douglas ${ }^{3}$ studied the nutrition knowledge and food practices of high school athletes. ${ }^{3}$ The average score of 940 athletes was 55\% on the nutrition knowledge section and the mean score on the food practice section was 2.2 out of 5. Females scored better on the nutrition knowledge section but males did better on the food practice section. Those athletes who competed in cross-country and track did the best on the nutrition knowledge section but baseball and football athletes had the lowest score. However, those athletes who participated in cross-country, football, lacrosse, soccer, swimming, and track and field scored the highest on the food practice section where field hockey and gymnastics athletes scored the lowest on the food practice section. Athletes who participated in more sports did better on the nutrition knowledge and food practice sections than those athletes who participated in fewer sports. ${ }^{3} \mathrm{~A}$ different study looked at the nutrition knowledge of adolescent male hockey players before and after nutrition education sessions. ${ }^{18}$ The average score on the nutrition knowledge test was $45 \%$ before nutrition education sessions. The nutrition education sessions helped to improve the athletes' nutrition knowledge. However, there was no statistical significance between scores on nutrition knowledge test and years involved in sport and age. ${ }^{18}$

Runners are known to have diets that are high in carbohydrates, but many do not eat enough food because they want to keep their weight down. This can lead to increased risk for stress fractures. Witta and Stombaugh ${ }^{2}$ did a 3-year study on adolescent female athletes. ${ }^{2}$ They 
administered a nutrition knowledge test and took a 3-day dietary food intake at the beginning of the study and then again 3 years later. ${ }^{2}$ The athletes scored better on the nutrition knowledge test the second time, but the average caloric intake dropped significantly from the first time to the second time. There was a significant drop in protein intake as well. The athletes ate less fat (31.7\% to $26.4 \%$ ), more carbohydrates (53.1\% to 59.6\%), and less calcium, potassium, and sodium in the second dietary intake analysis. Many of the athletes reported that they made changes in their diet, such as consuming less meat, soda, junk food, and eating more vegetables. The athletes also completed an Eating Attitudes Test (EAT). Those with a low EAT score had a higher caloric intake and higher score on the nutrition knowledge test while those with a high EAT score had a low caloric intake and a low score on the nutrition knowledge test. ${ }^{2}$

Poor eating habits can be even worse for athletes with a greater need for carbohydrates, protein, fat, vitamins, and minerals. Schmalz ${ }^{16}$ studied the nutrition practices and beliefs of adolescent athletes. ${ }^{16}$ Schmalz found that $46 \%$ reported eating cereal with whole or skim milk for breakfast, $21 \%$ were eating “other” breakfasts, $13 \%$ did not eat breakfast, $11 \%$ mainly were eating donuts, coffee, and juice for breakfast. The majority of the subjects ate lunch. Some of the subjects packed their lunch, bought school lunch, or a combination of both. Sixty-one percent of the subjects ate a high-fat lunch and $7 \%$ ate "junk" food for lunch. Only $26 \%$ of the subjects actually ate a well-balanced lunch. Sixty-one percent did not drink whole or chocolate milk at least three times a day. Surprisingly, a majority of the subjects consumed a good amount of water with $21 \%$ drinking one glass of water or less, $22 \%$ drank more than 5 glasses of water a day, and 27\% drank 3-5 glasses of water daily. Three percent of the athletes were under the supervision of a coach, school nurse, or physician for "training diets." Seven percent made up their own "training diets." Twenty-one percent practiced carbohydrate loading, 9\% used a high protein diet, and $2 \%$ admitted to using steroids or other muscle inducers. The subjects were also 
given a true-false nutrition test. Ironically, sixty-five percent believed that caffeine caused dehydration and impaired performance. Eighty-five percent believe that drinking water is beneficial. Ninety-five percent knew that a balanced diet is important. Fifty-five percent incorrectly believed that steak and eggs are a good pre-competition meal. Forty-five percent felt that it was okay to use soda, honey, and other high sugar foods for quick energy before competition. Fifty-two percent believed that protein supplements helped increase muscle size and $48 \%$ believed protein supplements did not help increase muscle size. Seventy-five percent of the students believed that a vegetarian diet provides enough protein for the student-athlete. ${ }^{16}$ Calcium is an important nutrient for development of bones and proper functioning of muscles, which is important for athletes. Bateson and Finch ${ }^{13}$ studied the calcium intake of adolescents. ${ }^{13}$ They found that adolescents do not consume enough calcium daily. They also found that boys consume more calcium than girls even though girls are more knowledgeable about calcium. ${ }^{13}$

Although adolescents are not consuming enough RDA for some vitamins and minerals, some might be using dietary supplements such as multivitamins as a way to make up for the lack in their diet. Perko et al, ${ }^{33}$ studied the influences on adolescent athletes use or non-use of dietary supplements. ${ }^{33}$ Athletes from grades $9^{\text {th }}$ thru $12^{\text {th }}$ grade at nine different public middle and high schools participated in this study. The athletes were asked if they strongly agreed, agreed, had no opinion, disagreed, or strongly disagreed with the following statements. About $18 \%$ strongly agreed/agreed that most athletes their age need dietary supplements to improve sports performance. Twenty-seven percent strongly agreed/agreed that taking dietary supplements would help all athletes do better in sports. Thirty-two percent strongly agreed/agreed that taking dietary supplements is a safe way for athletes to improve sports performance. However, 25\% strong agreed/agreed and 36\% did not know or had no opinion as to whether taking dietary supplements are safe because they are tested by scientists. The most surprising statement is that 
$63 \%$ of the athletes studied strongly agreed/agreed that dietary supplements were safe because professional athletes take them. Forty-one percent strongly agreed/agreed that dietary supplements give you more energy, $32.7 \%$ strongly agreed/agreed that dietary supplements are a safe way to improve strength, and $44.8 \%$ strongly agreed/agreed that dietary supplements are a good way to build muscle. ${ }^{33}$

How are these athletes influenced to strongly agree/agree with these statements? The athletes gave a variety of opinions ( $41 \%$ no opinion, $32.7 \%$ strongly agreed/agreed, $25.4 \%$ strongly disagreed/disagreed) with the statement, "my coach would support my using dietary supplements to improve sports performance.” However, 41.8\% strongly agreed/agreed that their coach would support the athletes in taking dietary supplements for general health reasons. Fortysix percent strongly agreed/agreed that their parents would support them taking dietary supplements for general health reasons, but only $36 \%$ felt their parents would support them taking dietary supplement to improve athletic performance. Forty-four percent felt their teammates would support them using dietary supplements for general health reasons, and $46 \%$ felt their teammates would support them using dietary supplements to improve athletic performance. An interesting finding in this study is that $25 \%$ strongly agreed/agreed that doctors would support them taking dietary supplements to improve athletic performance, and $42.8 \%$ felt that the doctor would support them taking dietary supplements for general health reasons. The same is true as the athletes strongly agreed/agreed that athletic trainers were more likely to support them taking dietary supplements for general health reasons (43.5\%) than for athletic performance (38.1\%). Fifty-one percent strongly agreed/agreed they would take a dietary supplement to improve athletic performance and 56\% strongly agreed/agreed they would take a dietary supplement for general health reasons. ${ }^{33}$ 


\section{Studies On College Athletes}

Jonnalagadda ${ }^{15}$ et al studied the dietary practices and attitudes of collegiate freshman football players at a Division I school. ${ }^{15}$ They found that 26\% avoided sweets, $13 \%$ avoided fried foods, 10\% avoided fat and oils like mayonnaise, 7\% avoided fast foods, dairy, and fish, and 3\% avoided red meat. Fifty-two percent of the athletes studied avoided alcohol consumption. Twenty-six percent drank more than 5 cups of water during workouts. Fifty-two percent drank 3-5 cups of water during workouts, 19\% drank 1-2 cups of water during workouts and 3\% did not drink any water during workouts. Forty-two percent were taking some type of supplement with creatine (36\%) being the most popular. Other supplements noted were vitamins (23\%), protein shakes (13\%), herbs (7\%), amino acids, and energy boosters or energy bars (3\%). More than $50 \%$ of the athletes believed that protein is the main source of energy for the muscles, that protein supplements are needed for muscle growth and development, while vitamin and mineral supplements are necessary to increase levels of energy. The athletes also believed that sports drinks are not an appropriate substitute for water to replace fluid losses. ${ }^{15}$

Jacobson et $\mathrm{al}^{6}$ studied the nutrition practices and knowledge of collegiate varsity athletes. $^{6}$ More than $29 \%$ of the athletes studied knew the recommended amount of carbohydrate intake, whereas only $11.7 \%$ knew the recommended percent of protein and fat from the total number of daily calories. About $35 \%$ of men and $40 \%$ of women correctly identified the functions of vitamins. A significantly higher percentage of men than women thought vitamins help gain weight. Thirty percent incorrectly thought vitamins provide immediate energy and $14.7 \%$ felt they increase muscle strength. Fifty-two percent of men and 58\% of women knew the correct function of protein, although $21 \%$ believed that protein provides immediate energy. Seventy-nine percent of men and $65 \%$ of women had used a supplement with creatine (28.6\%) being the most popular supplement. About 19\% used vitamin/mineral supplements and 10\% used 
energy bars. ${ }^{6}$ A study by Rosenbloom et al ${ }^{14}$ studied Division I athletes nutrition knowledge and confirmed the results from the Jacobson et al ${ }^{6}$ study. ${ }^{14}$ They found that most of the athletes knew the importance of carbohydrates and water. They were unclear of protein's role in the body and its importance in the diet. The majority of the athletes knew that vitamins and minerals could give them energy. ${ }^{14}$

Nutrition knowledge and practices among collegiate female athletes and non-athletes were studied by Barr. ${ }^{20}$ College athletes are more likely to use nutrition supplements than nonathletes. Athletes use an iron supplement significantly more than non-athletes. Non-athletes and athletes scored about the same on the nutrition knowledge questionnaire. ${ }^{20}$ Zawila et al ${ }^{17}$ studied nutrition knowledge and attitudes of female collegiate cross-country runners at Division I, II, and III levels. ${ }^{17}$ Cross-country runners are known for being susceptible to eating disorders. However, they found that cross-country runners are receptive to nutrition education. Those who took a nutrition class scored better on the nutrition knowledge test then those who did not. Overall, cross-country runners did well on the athlete nutrition-related questions but not as well on the general nutrition-related questions. ${ }^{17}$ Another study of collegiate athletes mainly from Division III schools, found athletes' on average scored of 55\% on the nutrition knowledge test. ${ }^{7}$ Nutrition Source

Athletes rely on a multitude of sources for nutrition knowledge. The majority of athletes and non-athletes received their nutrition information from magazines, books, friends/teammates, and high school and community education courses. There was a significant difference in the source of nutrition information used between athletes and non-athletes. Athletes felt the coach was a good source of nutrition information but not the most useful source. The non-athletes did not think the coach was a good source for nutrition information. Varsity athletes did not use 
fitness classes, health food stores, and dietitians as often as the non-students for information on nutrition. $^{20}$

In a study by Witta ${ }^{2}$, more athletes had asked and received advice about diet and health mainly from coaches but also from parents, doctors, and teammates. ${ }^{2}$ Twenty-five percent of the athletes were unhappy about their weight. Forty-one percent felt pressure about their weight from coaches, parents, friends, fashion models, and themselves. ${ }^{2}$ The results were similar to a study of Division III schools, where athletes stated that their main nutrition sources came from parents and coaches. ${ }^{7}$

Nutrition practices and knowledge of collegiate varsity athletes were studied by Jacobson et al. ${ }^{6}$ They found that athletes often receive nutrition information. Women are more likely to receive nutrition information than men. Almost 22\% of the athletes studied received their nutrition information from strength and conditioning coordinators, 19\% from athletic trainers, 12.5\% from university nutrition classes, $10.6 \%$ from coaches, $10 \%$ from nutritionists, $10 \%$ from magazines, $5.5 \%$ from family members, $3.9 \%$ from friends, $2.3 \%$ from $\mathrm{TV}, 1 \%$ from team physicians, and 1.4 from other sources. ${ }^{6}$

Eddy et $\mathrm{al}^{5}$ studied the knowledge and influence of others on dietary supplements of high school athletes. ${ }^{5}$ Athletes from grade $6^{\text {th }}$ thru $12^{\text {th }}$ grade from nine public schools were studied. Athletic trainers had the most influence on adolescent attitudes towards dietary supplements. Parents and coaches were the next biggest influence on adolescent attitudes towards dietary supplements. ${ }^{5}$ The top nutrition source within the school was general science followed by home economics, and health education courses. The highest rated nutrition sources outside of school were parents followed by none of the listed choices, popular books and magazines. ${ }^{3}$ 
Nutrition Knowledge of Coaches, Athletic Trainers, and Physical Education Teachers

Many athletes go to their coaches for nutrition advice on how to lose weight, gain weight, get stronger, faster, and how to improve their performance. The problem is that many coaches have not taken a class in nutrition, but may have attended a workshop on nutrition or gained nutrition information from journals. Witta and Stombaugh ${ }^{2}$ found that cross country and track coaches told their athletes to eat high carbohydrate-rich foods, avoid fat, eat enough, eat at the end of a race, and pay attention to what works. ${ }^{2}$ Some coaches did not give any nutrition advice to their athletes. ${ }^{2}$

Collegiate athletes often seek out their coaches for nutrition information so the nutrition knowledge of college coaches' were studied. The average score on the college coaches nutrition knowledge test was $70 \% .{ }^{34}$ Parr et al ${ }^{19}$ studied the nutrition knowledge of coaches and found that $61 \%$ had no formal education in nutrition. Coaches ranked the items in order of importance. Fluid intake was the number one priority for the coach followed by weight, vitamins, pre-game meals, protein, carbohydrate loading, and minerals. Most of the coaches surveyed believed that they and the athletic trainers are responsible for nutrition guidance. Many coaches and athletes incorrectly believed that eating more protein will make the muscles bigger. ${ }^{19}$ Another similar study looking at athletic trainers and coaches at Division I institutions found that athletic trainers and coaches scored $67 \%$ on the nutrition knowledge questions. ${ }^{35}$ Those who coached or were athletic trainers for female sports did better on the nutrition knowledge questions than those coached or were athletic trainers for male sports. Those with 15 years or more experience or were strength and conditioning coaches did the best on the nutrition knowledge questions. ${ }^{35}$ Coaches and athletic trainers are usually closest to the athletes other than teammates, friends and family so the athletes may also consult them for nutrition information. ${ }^{7}$ Collegiate athletic trainers and coaches were given a nutrition test. Athletic trainers scored an average of $74 \%$ 
while the coaches averaged $64 \%$ on the nutrition test. Only $3 \%$ of the athletic trainers did not have any nutrition classes where as $37 \%$ of the coaches did not have any nutrition classes. Athletic trainers received most of their nutrition information from academic journals and nutrition faculty, while coaches received their nutrition information from athletic trainers and nutrition faculty. ${ }^{7}$

High school coaches may not have as much access to nutrition faculty as a college coaches. Baer et al. ${ }^{36}$ studied the knowledge of high school football coaches and how they advised their athletes to gain lean body mass. Ninety-eight percent had given advice to athletes on how to gain lean body mass. Ninety-seven percent felt nutrition was important when trying to gain lean body mass. All of the coaches advised the athletes to gain 1 to 3 pounds of lean body mass each week. Eighty percent of the coaches felt a diet high in carbohydrates and low in fat was important for athletic performance and to gain lean body mass. Ten percent felt that protein was important to help gain lean body mass but $30 \%$ felt protein supplements were important to gain lean body mass. None of the coaches knew the recommended protein range to help in gaining lean body mass. Sixty-five percent felt that vitamin or mineral supplements are helpful in gaining lean body mass. The coaches were asked what foods are important in gaining lean body mass. Thirty-three percent stated breads and cereals and $47 \%$ stated meat, fish, poultry, and beans were foods that need to be increased to gain lean body mass. Thirty-nine percent felt that increasing foods from the milk and dairy group helped to gain lean body mass. Only $14 \%$ felt that increasing the amount of fruits and vegetables was important to help gain lean body mass. The researches found that about 1 out of 3 coaches took a nutrition class or a continuing education program on nutrition. Three out of four coaches received their nutrition information from newspapers, magazines, or journals. None of the coaches that were studied consulted a nutritionist. ${ }^{36}$ 
Wrestling is a sport that is notorious for having eating disorders because of the constant weight loss throughout the season. Sossin et $\mathrm{al}^{37}$ studied the nutrition beliefs, attitudes, and resources of high school wrestling coaches. ${ }^{37}$ A majority of the coaches used magazines, textbooks, journals, or professional publications for nutrition information. However, about half of the coaches studied did consult with a dietitian or exercise physiologist. The older and more experienced coaches reported attending a sports nutrition workshop and felt they were very knowledgeable about sports nutrition. Ninety-one percent felt that wrestlers should not restrict carbohydrate rich food because wrestlers need the glycogen for energy. Forty-six percent of the coaches questioned believed that wrestlers should not restrict their calories to less than 1,800 calories a day. Most of the coaches were interested in learning more about sports nutrition and those topics related to wrestling. Overall, only 59\% correctly answered the training diets question, 57\% correctly answered the hydration questions, and 64\% answered the weight loss questions correctly. ${ }^{37}$

In another similar study on high school athletic trainers and coaches, found athletic trainers scored better on the nutrition knowledge test but both coaches and athletic trainers did not do well on questions dealing with nutrition and adolescents. ${ }^{38}$ Athletic trainers were more likely to use recommendations from experts than coaches. Athletic trainers attended more workshops, conferences, and courses on nutrition than coaches. Both coaches and athletic trainers had positive attitudes towards nutrition. Athletic trainers and coaches picked textbooks, workshops, and professional publications as top nutrition information source. Both athletic trainers and coaches stated that physicians were the top nutrition resource. Athletic trainers and coaches disagreed on who is responsible for giving nutrition information to their athletes. Fiftythree percent felt the coach is responsible for giving nutrition information. However, $38 \%$ of athletic trainers felt they were responsible for giving nutrition information to the athletes. 
Seventeen percent of coaches felt it was the athletic trainers responsibility to educate the athletes about nutrition, while $33 \%$ of athletic trainers felt it was the coaches responsibility to educate the athletes about nutrition. ${ }^{38}$

The nutrition knowledge of Texas high school coaches were studied. ${ }^{39}$ Of the coaches studied, only 10 coaches had taken a nutrition course. Sixty-six percent received their nutrition information from professional journals and 55\% read popular magazines and newspapers for nutrition knowledge. Eight-six percent gave nutrition information monthly. Ninety-two percent believe that the coach should take an active role in educating the athletes about nutrition. Ninety-six percent felt that participation in a nutrition course or workshop would be helpful, and 76\% felt a basic nutrition course should be required. The coaches' mean score on the nutrition knowledge test was $55 \%$, and 14 coaches scored $70 \%$ or above. The highest questions answered correctly were the general nutrition information and fluids and hydration questions. However, $34 \%$ knew that protein did not provide energy during short-term events and $66 \%$ felt that protein supplements help increase muscle mass. ${ }^{39}$

In many schools, physical education teachers are responsible for teaching the health classes. ${ }^{40}$ Cho and Fryer ${ }^{40}$ studied nutrition knowledge of junior, seniors, and graduate physical education majors compared to a control group of students, who were finishing a basic non-major nutrition course. The physical education majors scores were significantly lower than the control group. Most of the physical education majors did not take a college-level nutrition course. Female physical education majors scored significantly higher on the nutrition test than their male counterparts. The graduate physical education majors scored significantly higher on the nutrition test than the undergraduate physical education majors. ${ }^{40}$ 
Summary

It is important for athletes to eat 6-11 servings of carbohydrates, 3-5 servings of vegetables, 2-4 servings of fruits, 3 servings of calcium-rich products, and 2 servings from high proteins sources. This allows the athlete to receive enough carbohydrates, proteins, fats, vitamins and minerals that are important for the body to be able to maintain normal everyday functions and provide capabilities to repair and provide energy for the athlete. Athletes need to drink plenty of water to replace fluids lost during practices or competitions and to prevent dehydration that can hinder athlete performance. High school athletes lack proper nutrition knowledge. Many athletes lack the proper amount of calcium and iron in their diet. Most of the high school athletes that were studied ate junk food or foods high in fat. High school athletes received their nutrition information from coaches, school, family, and media sources. The collegiate athletes understand the importance of proper nutrition practices. Many of them receive their information from coaches, athletic trainers, classes, and magazines. Many times the coach or athletic trainer is asked to advise athletes about nutrition concerns. Many coaches do not have any formal nutrition education and receive most of their information from newspapers, magazines, or journals. Athletic trainers have more formal nutrition education then coaches but disagree on who is responsible for nutrition education for athletes. 


\section{APPENDIX C}

\section{ADDITIONAL METHODS}

Table C1: Cover Letter

February 23, 2004

Dear Waynesburg Central High School Athlete,

I am a West Virginia University graduate athletic training student and I am conducting research on the nutrition knowledge of high school athletes. The purpose of this study is to determine if high school athletes are receiving proper nutrition information. This research is being conducted to partially fulfill the requirements for the completion of the Master of Science degree in Athletic Training.

The following questionnaire includes 12 demographic questions and 27 multiple choice and true/false questions regarding general nutrition knowledge. The questionnaire should take approximately 20 minutes to complete. If there is any information you feel was left out of the questionnaire or any comments please feel free to include them when returning your questionnaire.

Coding will be used to keep track of your responses, but your name will not be associated with your responses. I will be the only person with access to the information provided. Your responses will remain anonymous and confidential. Participation in this study is completely voluntary and you are not required to answer every question. Your grades, position on the team nor injury evaluation, and treatment will not be affected by refusing to participate. You have the right to withdrawal any data you submit at any time. Completing and returning this questionnaire will serve as your consent to participate. If you choose to participate, please complete the questionnaire and return the questionnaire in the manila envelop in the front of the room.

If you have any questions or concerns, please feel free to contact Charis Mitchell by phone at (724)-852-1050 x 241 or via e-mail at cmitche3@mix.wvu.edu. You may also contact my supervisor, Dr. Michelle Sandrey at (304)-293-3295 x 5220 or msandrey@mail.wvu.edu with any questions regarding this research.

Thank you in advance for you participation.

Sincerely

Charis Mitchell, ATC

*This study was approved by the Institutional Review Board (IRB) of West Virginia University and The School of Physical Education. 
Table C2.: Questionnaire

Demographic Information

Code:

Please answer the following questions by circling the answer or fill in the blank space.

1. Year in school: Freshman Sophomore Junior Senior

2. Gender: Male Female

3. Age

4. Which school based sports have you participated in this past year (circle all that apply):

$\begin{array}{lll}\text { Football } & \text { Soccer } & \text { Volleyball } \\ \text { Cross Country } & \text { Basketball } & \text { Wrestling } \\ \text { Track } & \text { Baseball } & \text { Softball } \\ \text { Cheerleading } & \text { Golf } & \end{array}$

Cheerleading Golf

5. Which one of the above sport(s) circled is your main sport of interest?

6. What year in school were you in when you took a health class?

Freshman Sophomore Junior Senior Have not taken it yet

7. Did/do you talk about nutrition in that health class? Yes No

8. Where do you receive your knowledge about nutrition (circle all that apply):
A. Magazine
F. School Nurse
K. Dietitian
B. TV
G. Doctor
L. Class
C. Books
H. Parents/Family
M. Other:
D. Coaches
I. Friends
E. Athletic Trainer
J. Teammates
N. Other:
O. Other:

9. Rank your top three sources of nutrition information that were circled above (\#1 is the most important).
1.
2.
3.

10. Top three reasons why these sources are useful? (\#1 is the most useful)

1.

2.

3.

11. Have you attended any additional nutrition classes, seminars, or talks? Yes No what topics?

12. Are food advertisements a very reliable source of nutrition information?

Yes No 


\section{Nutrition Knowledge Questionnaire}

Please circle the response option that you believe is the best answer to each of the following questions.

1. The main energy source for athletes are
A. Carbohydrates
B. Proteins
C. Fats

2. Carbohydrates and protein have the same caloric value.
A. True
B. False

3. Eating a lot of food with high amounts of protein increase muscle size?
A. True
B. False

4. Protein is the primary source of energy for muscles.
A. True
B. False

5. The Food Guide Pyramid recommends everyone should consume serving(s) a day from the protein group?
A. Unlimited
B. 1
C. 2

6. A serving size for the protein group is
A. 3 oz meat
B. 5 eggs
C. 1 tablespoon peanut butter
D. All of the above

7. The Food Guide Pyramid recommends 6-11 servings from bread, cereal, and pasta group.
A. True
B. False

8. A serving size for the breads, cereal, and pasta group is ?
A. one slice of bread
B. $1 / 2$ cup rice
C. $3 / 4$ cup cold cereal
D. All of the above 
9. Fruits and vegetables are important because they provide vitamins and minerals
A. True
B. False

10. The Food Guide Pyramid recommends everyone consume vegetables a day:
A. $2-4$
B. $3-5$
C. Vegetables are not really important

11. A serving size for the vegetable groups is
A. 1 cup carrots
B. 2 cups lettuce
C. $1 / 2$ cup green beans
D. All of the above

12. The Food Guide Pyramid recommends everyone consume fruits a day:
A. 3-5
B. $1-3$
C. $2-4$

13. A serving size for the fruit group is
A. 10 grapes
B. 1 cup applesauce
C. 16 oz orange juice
D. 1 piece of fresh fruit

14. The Food Guide Pyramid recommends servings of calcium rich products be consumed a day.
A. As many as possible
B. 3
C. 2

15. A serving size for the dairy group is
A. 8 oz milk
B. 2 cups yogurt
C. 2 oz cheese
D. All of the above

16. Orange juice is one of the best food sources of Vitamin C.
A. True
B. False

17. A good source of vitamin A is
A. Carrots
B. Potatoes
C. Celery 
18. What is the first step to take to lose weight?
A. Stop drinking water
B. Skip meals
C. Decrease the consumption of sweets, pastries, candy, etc

19. A proper diet consists of 50-65\% carbohydrates, less than $30 \%$ fat, and $12-15 \%$ protein.
A. True
B. False

20. The type of food eaten affects athletic performance.
A. True
B. False

21. A diet low in cholesterol and saturated fat may help prevent heart disease.
A. True
B. False

22. While in season, athletes need to eat a lot of steak and potatoes.
A. True
B. False

23. A pre-game meal should consist of a meal easy to digest, low in fat, high in carbohydrates and be eaten 2-3 hours before the event.
A. True
B. False

24. Fluids should be ingested before, during, and after practices and competitions?
A. True
B. False

25. Athletes should rely on thirst to ensure fluid replacement during and after competitions?
A. True
B. False

26. Gatorade and other sports drinks are better than water for replacing fluids lost during practices and competitions?
A. True
B. False

27. Butter, potato chips, and soda should be eaten
A. Unlimited
B. Often
C. Sparingly 


\section{APPENDIX D}

Table D1. School Based Sports

\begin{tabular}{lll}
\hline Sport & Frequency of sport participation & Primary Sport of Interest \\
\hline Track & $33.8 \%, \mathrm{n}=47$ & $12.9 \%, \mathrm{n}=22$ \\
Football & $30.9 \%, \mathrm{n}=43$ & $20.1 \%, \mathrm{n}=28$ \\
Basketball & $23 \%, \mathrm{n}=32$ & $11.5 \%, \mathrm{n}=16$ \\
Soccer & $21.6 \%, \mathrm{n}=30$ & $15.8 \%, \mathrm{n}=22$ \\
Baseball & $16.5 \%, \mathrm{n}=23$ & $9.4 \%, \mathrm{n}=13$ \\
Softball & $15.8 \%, \mathrm{n}=22$ & $9.4 \%, \mathrm{n}=13$ \\
Wrestling & $15.1 \%, \mathrm{n}=21$ & $5 \%, \mathrm{n}=7$ \\
Cheerleading & $7.9 \%, \mathrm{n}=11$ & $5 \%, \mathrm{n}=7$ \\
Volleyball & $7.2 \%, \mathrm{n}=10$ & $5 \%, \mathrm{n}=7$ \\
Cross-country & $5.8 \%, \mathrm{n}=8$ & $3.6 \%, \mathrm{n}=5$ \\
Golf & $3.6 \%, \mathrm{n}=5$ & $1.4 \%, \mathrm{n}=2$ \\
\hline
\end{tabular}

Table D2. Nutrition Knowledge Sources

\begin{tabular}{lll}
\hline Nutrition Source & Percent & Number \\
\hline Doctor & 55.4 & 77 \\
Athletic Trainer & 51.8 & 72 \\
Parents/Family & 51.1 & 71 \\
Coaches & 47.5 & 66 \\
TV & 46 & 64 \\
Magazine & 42.4 & 59 \\
Class & 39.6 & 55 \\
Friends & 25.2 & 35 \\
Books & 23 & 32 \\
Teammates & 20.1 & 28 \\
School Nurse & 18 & 25 \\
Dietitian & 7.9 & 11 \\
Other - cereal boxes & 1.4 & 2 \\
Other - health store & 1.4 & 2 \\
Other - internet & .7 & 1 \\
Other - no where & .7 & 1 \\
Other - personal trainer & .7 & 1 \\
Other - stores & .7 & 1 \\
\hline
\end{tabular}

Table D3. Nutrition Source by Year in school

\begin{tabular}{|c|c|c|c|c|c|c|c|}
\hline Source & Freshman $(\mathrm{n}=32)$ & $\begin{array}{l}\text { Sophomore } \\
(n=38)\end{array}$ & Junior $(\mathrm{n}=45)$ & Senior $(n=24)$ & $\chi^{2}$ & $\mathrm{P}$ & CC \\
\hline Magazine $^{\text {ns }}$ & $31.2 \%$ & $34.2 \%$ & $60 \%$ & $37.5 \%$ & 8.61 & .04 & .24 \\
\hline $\mathrm{TV}^{\mathrm{ns}}$ & 46.95 & $31.6 \%$ & $64.4 \%$ & $33.3 \%$ & 10.90 & .012 & .27 \\
\hline Books ${ }^{\text {ns }}$ & $31.3 \%$ & $15.8 \%$ & $15.6 \%$ & $37.9 \%$ & 6.6 & .09 & .21 \\
\hline Coaches $^{\text {ns }}$ & $40.6 \%$ & $36.8 \%$ & $55.6 \%$ & $58.3 \%$ & 4.64 & .20 & .18 \\
\hline Athletic Trainerns & $46.9 \%$ & $50 \%$ & $60 \%$ & $45.8 \%$ & 1.91 & .59 & .12 \\
\hline School Nurse ${ }^{\text {ns }}$ & $28.1 \%$ & $5.3 \%$ & $22.2 \%$ & $16.7 \%$ & 6.98 & .07 & .22 \\
\hline Doctor $^{\text {ns }}$ & $50 \%$ & $55.3 \%$ & $57.8 \%$ & $58.3 \%$ & .56 & .91 & .06 \\
\hline Parents/family ${ }^{\text {ns }}$ & $50 \%$ & $47.4 \%$ & $55.6 \%$ & $50 \%$ & .60 & .90 & .07 \\
\hline Friends $^{\text {ns }}$ & $25 \%$ & $21.1 \%$ & $22.2 \%$ & $37.5 \%$ & 2.49 & .48 & .13 \\
\hline Teammates* & $15.6 \%$ & $5.3 \%$ & $26.7 \%$ & $37.5 \%$ & 11.32 & .01 & .27 \\
\hline Dietitians $^{\text {ns }}$ & $6.3 \%$ & $13.2 \%$ & $4.4 \%$ & $8.3 \%$ & 2.31 & .51 & .13 \\
\hline .Class ${ }^{\mathrm{ns}}$ & $59.4 \%, n=19$ & $23.7 \%, n=9$ & $40 \%, n=18$ & $37.55, n=9$ & 9.31 & .03 & .25 \\
\hline Other ${ }^{\mathrm{ns}}$ & $0 \%, \mathrm{n}=0$ & $7.9 \%, n=3$ & $11 \%, n=5$ & $0 \%, n=0$ & 18.77 & .41 & .35 \\
\hline
\end{tabular}


Table D4. Nutrition Source by Gender

\begin{tabular}{|c|c|c|c|c|c|c|c|c|c|}
\hline Source & \multicolumn{2}{|c|}{ Male $(n=82)$} & \multicolumn{2}{|c|}{ Female $(n=57)$} & $\chi^{2}$ & \multicolumn{2}{|l|}{$\mathrm{P}$} & \multicolumn{2}{|l|}{$\mathrm{CC}$} \\
\hline Magazines ${ }^{\mathrm{ns}}$ & \multicolumn{2}{|c|}{$34.1 \%$} & \multicolumn{2}{|c|}{$54.4 \%$} & 5.64 & \multicolumn{2}{|l|}{.014} & \multicolumn{2}{|l|}{.20} \\
\hline $\mathrm{TV}^{\mathrm{ns}}$ & \multicolumn{2}{|l|}{$45.1 \%$} & \multicolumn{2}{|l|}{$47.4 \%$} & .07 & \multicolumn{2}{|l|}{.46} & \multicolumn{2}{|l|}{.02} \\
\hline Books $^{\text {ns }}$ & \multicolumn{2}{|l|}{$20.7 \%$} & \multicolumn{2}{|l|}{$26.3 \%$} & .59 & \multicolumn{2}{|l|}{.44} & \multicolumn{2}{|l|}{.44} \\
\hline Coaches $^{\text {ns }}$ & \multicolumn{2}{|l|}{$53.7 \%$} & \multicolumn{2}{|l|}{$38.6 \%$} & 3.06 & \multicolumn{2}{|l|}{.06} & \multicolumn{2}{|l|}{.15} \\
\hline Athletic Trainer* & \multicolumn{2}{|l|}{$70.7 \%$} & \multicolumn{2}{|l|}{$24.6 \%$} & 28.71 & \multicolumn{2}{|l|}{.000} & \multicolumn{2}{|l|}{.41} \\
\hline School Nurse ${ }^{\text {ns }}$ & $19.5 \%$ & & $15.8 \%$ & 3. & & .37 & & .05 & \\
\hline Doctor $^{\mathrm{ns}}$ & $48.8 \%$ & & $64.9 \%$ & 3. & & .04 & & .16 & \\
\hline Parents/family ${ }^{\mathrm{ns}}$ & $47.6 \%$ & & $56.1 \%$ & .9 & & .32 & & .08 & \\
\hline Friends $^{\mathrm{ns}}$ & $24.4 \%$ & & $26.3 \%$ & .0 & & .47 & & .02 & \\
\hline Teammates $^{\mathrm{ns}}$ & $23.2 \%$ & & $15.8 \%$ & 1. & & .20 & & .09 & \\
\hline Dietitian $^{\text {ns }}$ & $3.7 \%$ & & $14 \%$ & 4. & & .03 & & .19 & \\
\hline Class $^{\text {ns }}$ & $36.6 \%$ & & $43.9 \%$ & .7 & & .25 & & .07 & \\
\hline Other $^{\text {ns }}$ & $8.4 \%$ & & $1.8 \%$ & 6. & & .37 & & .21 & \\
\hline Table D5. Nutriti & Source by & Primary & Sport & & & & & & \\
\hline Source & $\begin{array}{l}\text { Football } \\
(n=43)\end{array}$ & $\begin{array}{l}\text { Soccer } \\
(n=30)\end{array}$ & $\begin{array}{l}\text { Track } \\
(n=47)\end{array}$ & $\begin{array}{l}\text { Basketball } \\
(\mathrm{n}=32)\end{array}$ & $\begin{array}{l}\text { Baseball } \\
(n=23)\end{array}$ & $\begin{array}{l}\text { Softball } \\
(n=22)\end{array}$ & $\chi^{2}$ & $\mathrm{P}$ & $\mathrm{CC}$ \\
\hline Magazine $^{\text {ns }}$ & $35.7 \%$ & 36.45 & $50 \%$ & $31.3 \%$ & $46.2 \%$ & $38.5 \%$ & 15 & .13 & .13 \\
\hline $\mathrm{TV}^{\mathrm{ns}}$ & $46.4 \%$ & $40.9 \%$ & $55.6 \%$ & $43.8 \%$ & $43.8 \%$ & $46.2 \%$ & 7.18 & .71 & .22 \\
\hline Books $^{\text {ns }}$ & $14.3 \%$ & $13.6 \%$ & $22.2 \%$ & $25 \%$ & $23.1 \%$ & $30.8 \%$ & 14.44 & .15 & .31 \\
\hline Coaches $^{\text {ns }}$ & $64.3 \%$ & $54.2 \%$ & $22.2 \%$ & $37.5 \%$ & $38.5 \%$ & $46.2 \%$ & 12.28 & .27 & .29 \\
\hline Athletic Trainer* & $75 \%$ & $50 \%$ & $22.2 \%$ & $37.5 \%$ & $61.5 \%$ & $38.5 \%$ & 24.79 & .006 & .39 \\
\hline School Nurse ${ }^{\text {ns }}$ & $10.7 \%$ & $18.2 \%$ & $16.7 \%$ & $18.8 \%$ & $30.8 \%$ & $15.4 \%$ & 4.57 & .92 & .18 \\
\hline Doctor $^{\mathrm{ns}}$ & $39.3 \%$ & $50 \%$ & $50 \%$ & $68.8 \%$ & $53.8 \%$ & $61.5 \%$ & 10.65 & .39 & .27 \\
\hline Parents/family ${ }^{\text {ns }}$ & $42.9 \%$ & $59.1 \%$ & $27.8 \%$ & $56.3 \%$ & $46.2 \%$ & $76.9 \%$ & 11.55 & .32 & .28 \\
\hline Teammates $^{\text {ns }}$ & $17.9 \%$ & $13.6 \%$ & $16.7 \%$ & $6.3 \%$ & $23.1 \%$ & $30.8 \%$ & 9.02 & .53 & .25 \\
\hline Friends $^{\mathrm{ns}}$ & $21.4 \%$ & $18.2 \%$ & $11.1 \%$ & $18.8 \%$ & $30.8 \%$ & $46.2 \%$ & 8.35 & .60 & .24 \\
\hline Class $^{\mathrm{ns}}$ & $35.7 \%$ & $36.4 \%$ & $44.4 \%$ & $31.3 \%$ & $38.5 \%$ & $46.2 \%$ & 2.53 & .99 & .13 \\
\hline Dietician $^{\text {ns }}$ & $0 \%$ & $9.1 \%$ & $5.6 \%$ & $6.3 \%$ & $7.7 \%$ & $15.4 \%$ & 5.95 & .82 & .20 \\
\hline Other ${ }^{\mathrm{ns}}$ & $10.7 \%$ & $4.5 \%$ & $5.6 \%$ & $12.6 \%$ & $7.7 \%$ & $0 \%$ & 42.117 & .96 & .48 \\
\hline
\end{tabular}


Table D6. Primary, Secondary, and Tertiary Nutrition Source

\begin{tabular}{llll}
\hline Nutrition Source & Primary Nutrition Source & Secondary Nutrition Source & Tertiary Nutrition Source \\
\hline Doctor & $16.5 \%, \mathrm{n}=23$ & $8.6 \%, \mathrm{n}=12$ & $13.7 \%, \mathrm{n}=9$ \\
Parents/family & $15.8 \%, \mathrm{n}=22$ & $9.4 \%, \mathrm{n}=13$ & $10.1 \%, \mathrm{n}=14$ \\
Athletic Trainer & $11.5 \%, \mathrm{n}=16$ & $11.5 \%, \mathrm{n}=16$ & $7.2 \%, \mathrm{n}=10$ \\
Class & $10.8 \%, \mathrm{n}=15$ & $5 \%, \mathrm{n}=7$ & $10.1 \%, \mathrm{n}=14$ \\
Magazine & $10.8 \%, \mathrm{n}=15$ & $8.6 \%, \mathrm{n}=12$ & $7.2 \%, \mathrm{n}=10$ \\
Coaches & $10.1 \%, \mathrm{n}=14$ & $12.9 \%, \mathrm{n}=18$ & $10.8 \%, \mathrm{n}=15$ \\
TV & $6.5 \%, \mathrm{n}=9$ & $15.1 \%, \mathrm{n}=21$ & $10.1 \%, \mathrm{n}=14$ \\
Books & $2.2 \%, \mathrm{n}=3$ & $8.6 \%, \mathrm{n}=12$ & $2.2 \%, \mathrm{n}=3$ \\
Dietitian & $2.2 \%, \mathrm{n}=3$ & $.7 \%, \mathrm{n}=1$ & $.7 \%, \mathrm{n}=1$ \\
Other-cereal & $1.4 \%, \mathrm{n}=2$ & $0 \%, \mathrm{n}=0$ & $0 \%, \mathrm{n}=0$ \\
boxes & & & \\
Friends & $1.4 \%, \mathrm{n}=2$ & $2.2 \%, \mathrm{n}=3$ & $6.5 \%, \mathrm{n}=9$ \\
Other-personal & $.7 \%, \mathrm{n}=1$ & $0 \%, \mathrm{n}=0$ & $0 \%, \mathrm{n}=0$ \\
trainer & & & \\
Other-stores & $.7 \%, \mathrm{n}=1$ & $0 \%, \mathrm{n}=0$ & $0 \%, \mathrm{n}=0$ \\
Teammates & $.7 \%, \mathrm{n}=1$ & $1.4 \%, \mathrm{n}=2$ & $2.9 \%, \mathrm{n}=4$ \\
Other-health store & $0 \%, \mathrm{n}=0$ & $.7 \%, \mathrm{n}=1$ & $.7 \%, \mathrm{n}=1$ \\
Other-internet & $0 \%, \mathrm{n}=0$ & $.7 \%, \mathrm{n}=1$ & $0 \%, \mathrm{n}=0$ \\
School Nurse & $0 \%, \mathrm{n}=0$ & $2.2 \%, \mathrm{n}=3$ & $.7 \%, \mathrm{n}=1$ \\
Missing & $8.6 \%, \mathrm{n}=12$ & $12.2 \%, \mathrm{n}=17$ & $17.3 \%, \mathrm{n}=24$ \\
\hline
\end{tabular}

Table D7. Descriptive Statistics for Number Correct by Year in School and Primary Sport

\begin{tabular}{llll}
\hline Variable & \# of Questions Answered Correctly & Standard Deviation & N \\
\hline Freshmen & 15.63 & 3.99 & 32 \\
Sophomore & 13.79 & 4.29 & 38 \\
Junior & 16.04 & 3.33 & 45 \\
Senior & 15.75 & 3.49 & 24 \\
Football & & & 28 \\
Soccer & 13.57 & 3.81 & 22 \\
Track & 16.64 & 3.94 & 18 \\
Basketball & 15.22 & 3.1 & 16 \\
Baseball & 15.44 & 3.94 & 13 \\
Softball & 15.15 & 2.30 & 7 \\
Cross-country & 14.85 & 5.0 & 7 \\
Wrestling & 18.43 & 4.54 & 7 \\
Volleyball & 14.14 & 4.14 & 5 \\
Cheerleading & 16.43 & 3.6 & 2 \\
Golf & 15.40 & 4.04 & \\
\hline
\end{tabular}


Table D8. Descriptive Statistics for the 5 Groupings by Year in School

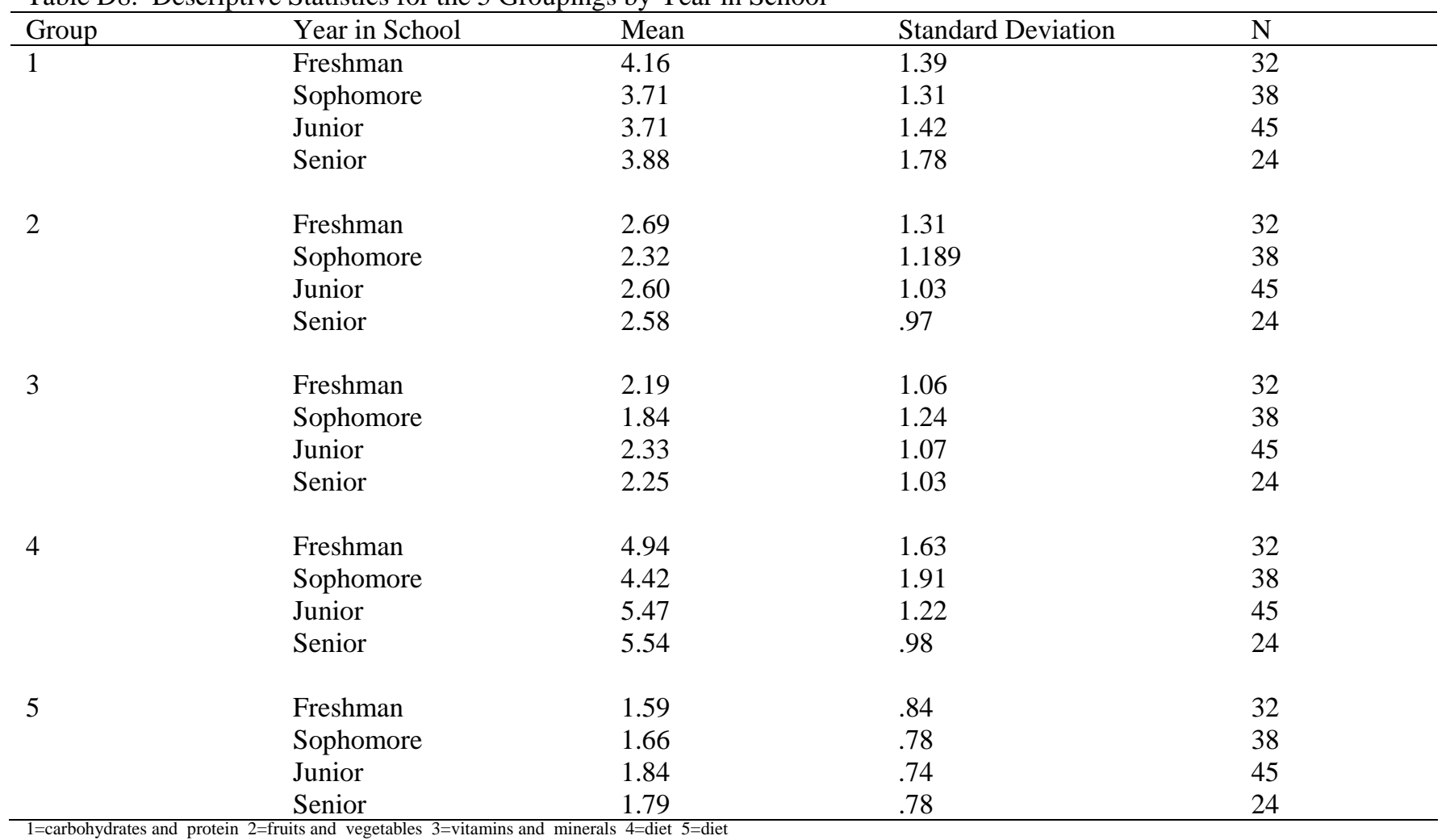

Table D9. Descriptive Statistics for 5 Groupings by Gender

\begin{tabular}{|c|c|c|c|c|}
\hline Group & Gender & Mean & Standard Deviation & $\mathrm{N}$ \\
\hline \multirow[t]{2}{*}{1} & Male & 3.98 & 1.5 & 82 \\
\hline & Female & 3.65 & 1.37 & 57 \\
\hline 2 & Female & 2.70 & 1.2 & 57 \\
\hline \multirow[t]{2}{*}{4} & Male & 4.96 & 1.58 & 82 \\
\hline & Female & 5.23 & 1.51 & 57 \\
\hline 5 & Male & 1.66 & .80 & 82 \\
\hline
\end{tabular}


Table D10. Descriptive Statistics for 5 Groupings by Top 6 Primary Sport

\begin{tabular}{|c|c|c|c|c|}
\hline Group & Primary Sport & Mean & Standard Deviation & $\mathrm{N}$ \\
\hline \multirow[t]{6}{*}{1} & Football & 3.71 & 1.44 & 28 \\
\hline & Soccer & 3.95 & 1.5 & 22 \\
\hline & Track & 3.41 & 1.58 & 18 \\
\hline & Basketball & 4.19 & 1.42 & 16 \\
\hline & Baseball & 3.54 & 1.27 & 13 \\
\hline & Softball & 2.92 & 1.44 & 13 \\
\hline \multirow[t]{6}{*}{2} & Football & 2.43 & 1.20 & 28 \\
\hline & Soccer & 2.68 & 1.25 & 22 \\
\hline & Track & 2.65 & 1.0 & 18 \\
\hline & Basketball & 2.31 & .87 & 16 \\
\hline & Baseball & 2.08 & .64 & 13 \\
\hline & Softball & 2.62 & 1.45 & 13 \\
\hline \multirow[t]{6}{*}{3} & Football & 1.86 & 1.17 & 28 \\
\hline & Soccer & 2.45 & 1.01 & 22 \\
\hline & Track & 2.41 & 1.00 & 18 \\
\hline & Basketball & 1.81 & .75 & 16 \\
\hline & Baseball & 2.46 & 1.13 & 13 \\
\hline & Softball & 2.38 & 1.33 & 13 \\
\hline \multirow[t]{6}{*}{4} & Football & 4.21 & 1.71 & 28 \\
\hline & Soccer & 5.64 & 1.62 & 22 \\
\hline & Track & 5.18 & 1.59 & 18 \\
\hline & Basketball & 5.06 & 1.77 & 16 \\
\hline & Baseball & 5.54 & 1.05 & 13 \\
\hline & Softball & 4.85 & 1.25 & 13 \\
\hline \multirow[t]{6}{*}{5} & Football & 1.36 & .87 & 28 \\
\hline & Soccer & 1.95 & .84 & 22 \\
\hline & Track & 1.53 & .51 & 18 \\
\hline & Basketball & 2 & .63 & 16 \\
\hline & Baseball & 1.92 & .49 & 13 \\
\hline & Softball & 2 & .82 & 13 \\
\hline
\end{tabular}

Table D11. ANOVA Results for Total Number Correct by Year in School, Gender, and Primary Sport

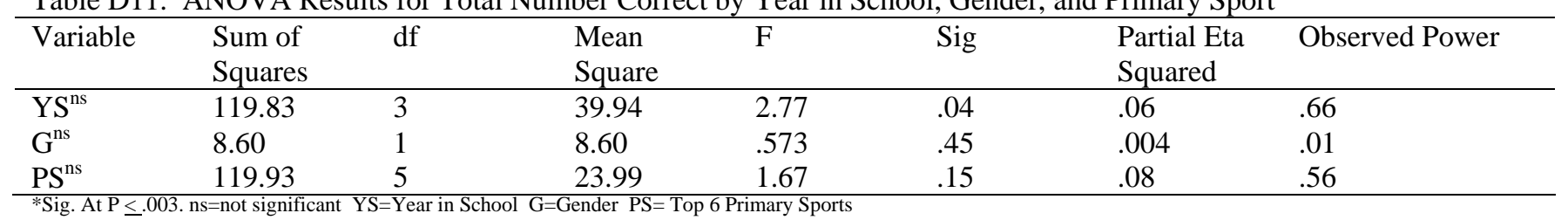


Table D12. Tukey’s Post-hoc Test for Total Number Correct for Year in School

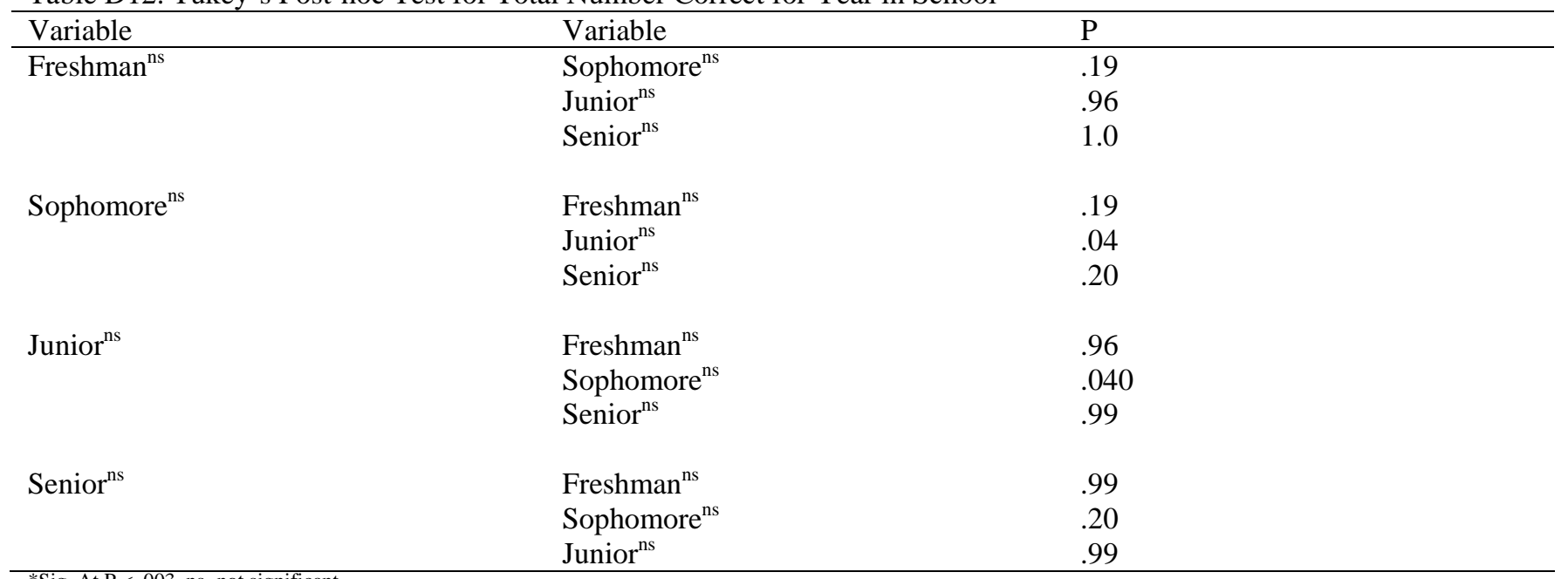

Table D13. Tukey’s Post-hoc Test for Total Number Correct for Top 6 Primary Sports

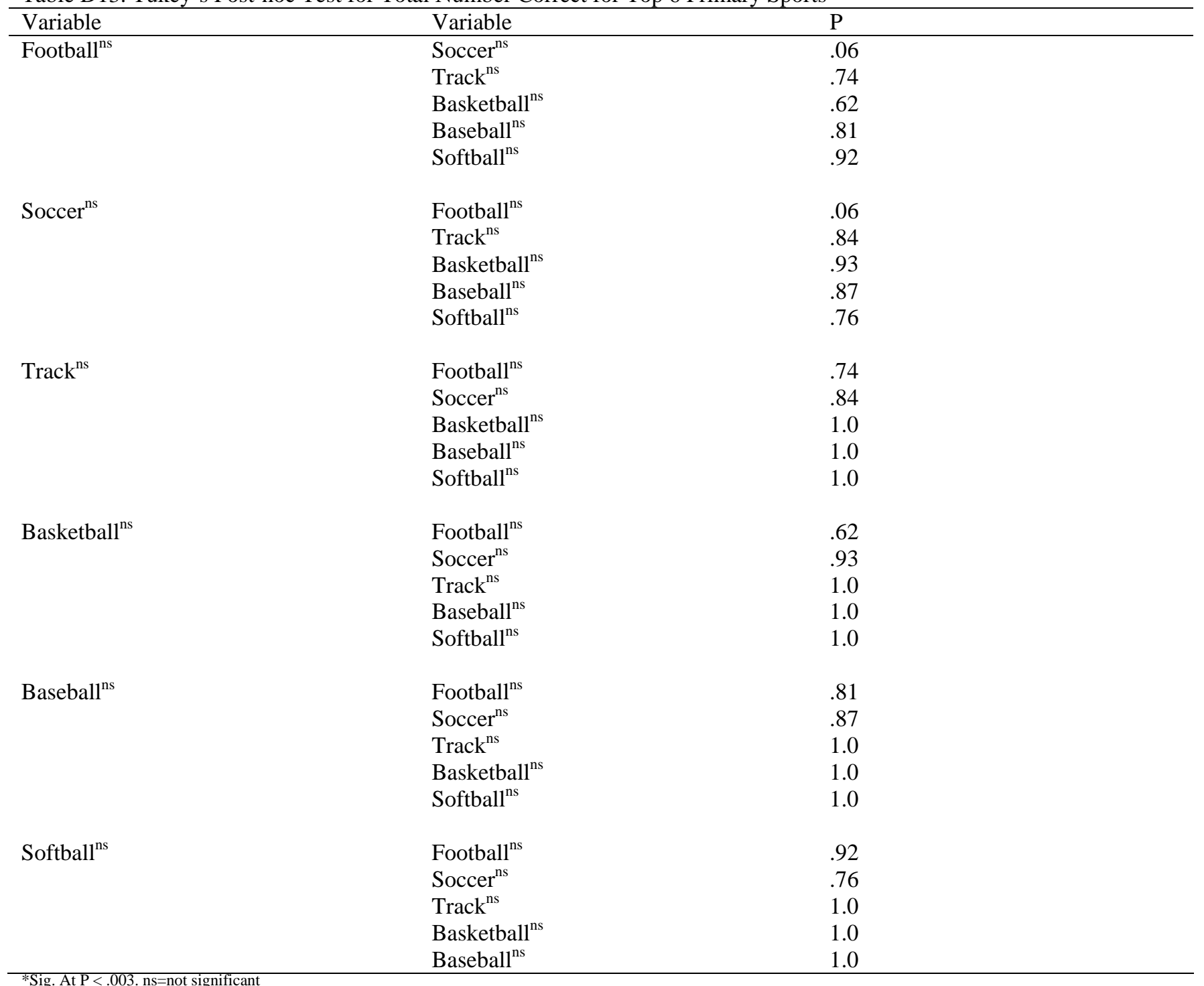


Table D14. ANOVA Results for Number Correct for the 5 Groupings by Year in School, Gender, and Primary Sport

\begin{tabular}{|c|c|c|c|c|c|c|c|c|}
\hline Variable & Group & $\begin{array}{l}\text { Sum of } \\
\text { Squares }\end{array}$ & $\mathrm{df}$ & $\begin{array}{l}\text { Mean } \\
\text { Square }\end{array}$ & $\mathrm{F}$ & Sig. & $\begin{array}{l}\text { Partial Eta } \\
\text { Squared }\end{array}$ & Observed Power \\
\hline \multirow[t]{5}{*}{ YS } & Group \# $1^{\text {ns }}$ & 4.61 & 3 & 1.54 & .73 & .54 & .02 & .03 \\
\hline & Group \# $2^{\text {ns }}$ & 2.81 & 3 & .94 & .73 & .54 & .02 & .03 \\
\hline & Group \# $3^{\text {ns }}$ & 5.40 & 3 & 1.8 & 1.46 & .23 & .03 & .09 \\
\hline & Group \# $4^{\text {ns }}$ & 28.98 & 3 & 9.66 & 4.29 & .006 & .09 & .52 \\
\hline & Group \# $5^{\text {ns }}$ & 1.47 & 3 & .49 & .81 & .49 & .02 & .04 \\
\hline \multirow[t]{5}{*}{ G } & Group \# $1^{\text {ns }}$ & 3.58 & 1 & 2.09 & 1.71 & .19 & .01 & .05 \\
\hline & Group \# $2^{\text {ns }}$ & 2.54 & 1 & 2.54 & 2.0 & .16 & .01 & .06 \\
\hline & Group \# $3^{\text {ns }}$ & 5.73 & 1 & 5.73 & .05 & .83 & .00 & .004 \\
\hline & Group \# $4^{\text {ns }}$ & 2.36 & 1 & 2.36 & .98 & .33 & .007 & .02 \\
\hline & Group \# $5^{\text {ns }}$ & .93 & 1 & .93 & 1.54 & .22 & .01 & .04 \\
\hline \multirow[t]{5}{*}{ PS } & Group \# $1^{\mathrm{ns}}$ & 14.73 & 5 & 2.95 & 1.4 & .23 & .06 & .14 \\
\hline & Group \# $2^{\text {ns }}$ & 4.24 & 5 & .85 & .68 & .64 & .03 & .04 \\
\hline & Group \# $3^{\text {ns }}$ & 9.21 & 5 & 1.84 & 1.58 & .17 & .07 & .17 \\
\hline & Group \# $4^{\text {ns }}$ & 30.85 & 5 & 6.17 & 2.48 & .04 & .11 & .37 \\
\hline & Group \# $5^{\text {ns }}$ & 8.27 & 5 & 1.65 & 3.01 & .01 & .19 & .50 \\
\hline \multicolumn{9}{|c|}{$\begin{array}{l}\text { *Sig. At } \mathrm{P} \leq .003 \text {. ns=not significan } \\
\text { minerals } 4=\text { diet } 5=\text { diet }\end{array}$} \\
\hline \multicolumn{9}{|c|}{ Table D15. Tukey’s Post-Hoc Test for Group Number 1 by Year in School } \\
\hline \multicolumn{3}{|c|}{ Variable } & \multicolumn{4}{|c|}{ Variable } & \multicolumn{2}{|c|}{$\mathrm{P}$} \\
\hline \multirow{3}{*}{\multicolumn{3}{|c|}{ Freshman $^{\text {ns }}$}} & \multicolumn{4}{|c|}{ Sophomore $^{\mathrm{ns}}$} & \multicolumn{2}{|c|}{.58} \\
\hline & & & \multicolumn{4}{|c|}{ Junior $^{\text {ns }}$} & \multicolumn{2}{|c|}{.55} \\
\hline & & & \multicolumn{4}{|c|}{ Senior $^{\text {ns }}$} & \multicolumn{2}{|c|}{.89} \\
\hline \multirow{3}{*}{\multicolumn{3}{|c|}{ Sophomore $\mathrm{ns}^{\mathrm{ns}}$}} & \multicolumn{4}{|c|}{ Freshman $^{\text {ns }}$} & \multicolumn{2}{|c|}{.58} \\
\hline & & & \multicolumn{4}{|c|}{ Junior $^{\text {ns }}$} & \multicolumn{2}{|c|}{1.0} \\
\hline & & & \multicolumn{4}{|c|}{ Senior $^{\text {ns }}$} & \multicolumn{2}{|c|}{.97} \\
\hline \multirow[t]{3}{*}{ Junior $^{\text {ns }}$} & & & \multicolumn{4}{|c|}{ Freshman $^{\text {ns }}$} & \multicolumn{2}{|c|}{.55} \\
\hline & & & \multicolumn{4}{|c|}{ Sophomore ${ }^{\text {ns }}$} & \multicolumn{2}{|c|}{1.0} \\
\hline & & & \multicolumn{4}{|c|}{ Senior $^{\text {ns }}$} & \multicolumn{2}{|c|}{.97} \\
\hline Senior ${ }^{\mathrm{ns}}$ & & & Fre & & & & .89 & \\
\hline & & & & & & & .97 & \\
\hline & & & Jur & & & & .97 & \\
\hline
\end{tabular}


Table D16. Tukey’s Post-hoc Test for Group Number 1 by Primary Sport

\begin{tabular}{|c|c|c|}
\hline Variable & Variable & $\mathrm{P}$ \\
\hline \multirow[t]{3}{*}{ Football $^{\mathrm{ns}}$} & Soccer $^{\mathrm{ns}}$ & .99 \\
\hline & Basketball $^{\mathrm{ns}}$ & .90 \\
\hline & Softball $^{\mathrm{ns}}$ & .59 \\
\hline \multirow[t]{4}{*}{ Soccer $^{\mathrm{ns}}$} & Football $^{\mathrm{ns}}$ & .99 \\
\hline & Basketball $^{\mathrm{ns}}$ & 1.0 \\
\hline & Baseball $^{\mathrm{ns}}$ & .96 \\
\hline & Softball $^{\mathrm{ns}}$ & .33 \\
\hline \multirow[t]{2}{*}{ Track $^{\text {ns }}$} & Football $^{\mathrm{ns}}$ & .98 \\
\hline & Soccer $^{\mathrm{ns}}$ & .86 \\
\hline \multirow[t]{5}{*}{ Basketball $^{\mathrm{ns}}$} & Football $^{\text {ns }}$ & .90 \\
\hline & Soccer $^{\mathrm{ns}}$ & .1 .0 \\
\hline & Track $^{\mathrm{ns}}$ & .64 \\
\hline & Baseball $^{\text {ns }}$ & .84 \\
\hline & Softball $^{\mathrm{ns}}$ & .19 \\
\hline \multirow[t]{4}{*}{ Baseball $^{\text {ns }}$} & Football $^{\mathrm{ns}}$ & 1.0 \\
\hline & Soccer $^{\text {ns }}$ & .96 \\
\hline & Track $^{\mathrm{ns}}$ & 1.0 \\
\hline & Basketball $^{\mathrm{ns}}$ & .84 \\
\hline
\end{tabular}

Table D17. Tukey’s Post-hoc Test for Group Number 2 by Year in School

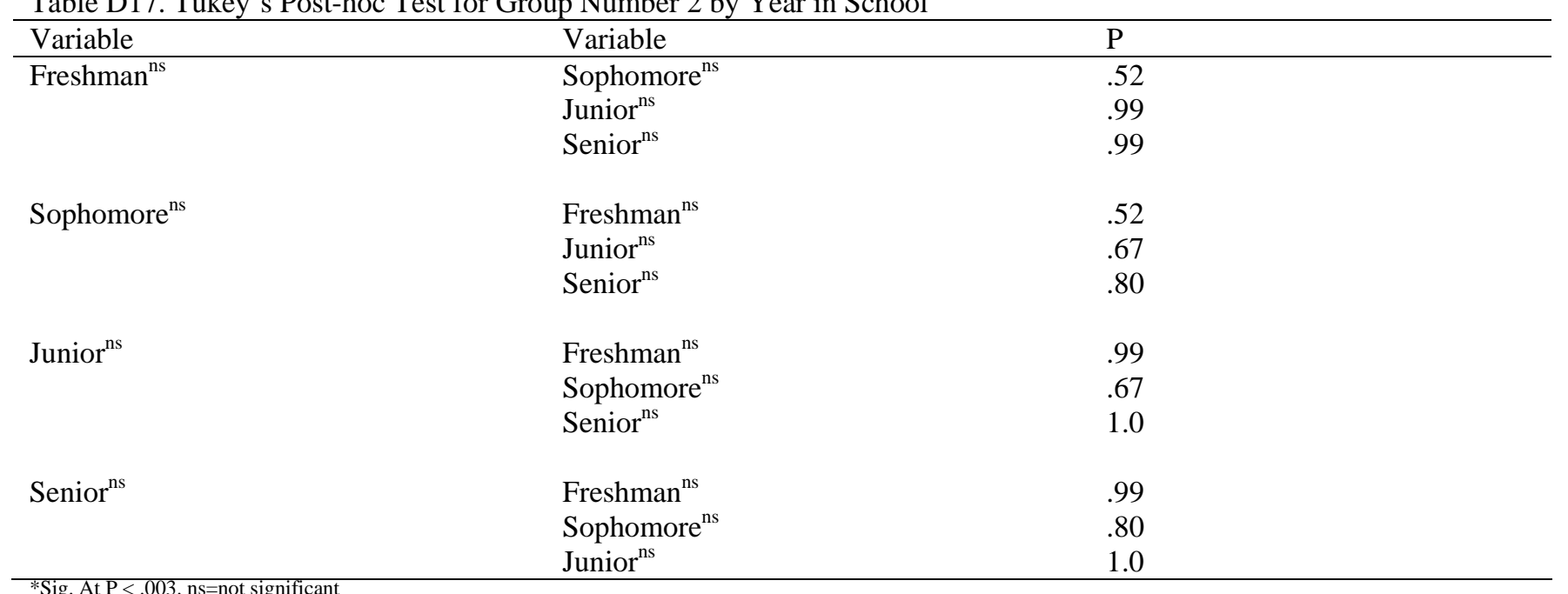

*Sig. At P $\leq .003$. ns=not significant 
Table D18. Tukey’s Post Hoc Test for Group Number 2 by Top 6 Primary Sports

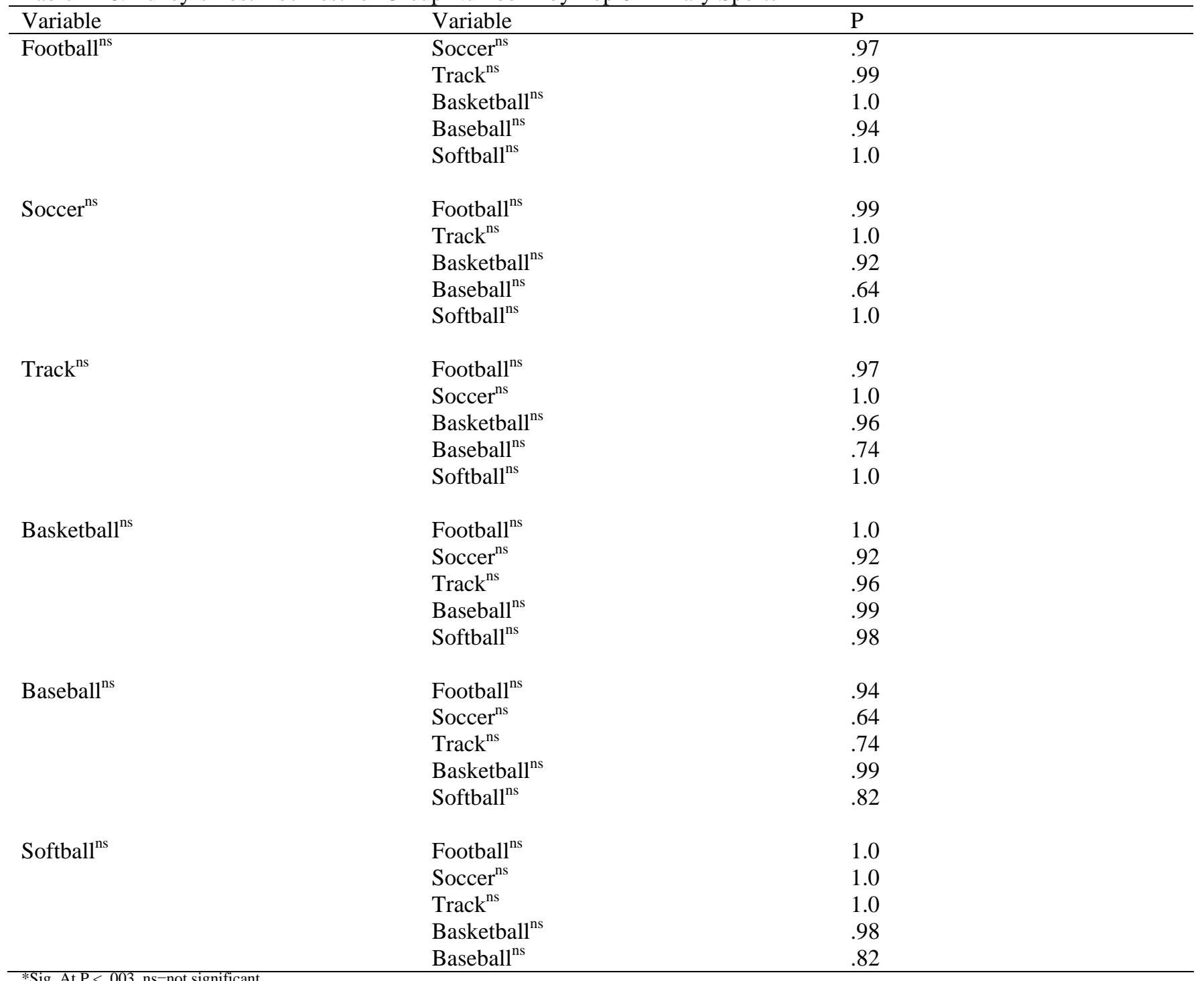

Table D19. Tukey’s Post-hoc Test for Group Number 3 by Year in School

\begin{tabular}{|c|c|c|}
\hline Variable & Variable & $\mathrm{P}$ \\
\hline \multirow[t]{3}{*}{ Freshman $^{\text {ns }}$} & Sophomore $^{\text {ns }}$ & .57 \\
\hline & Junior $^{\text {ns }}$ & .94 \\
\hline & Senior $^{\text {ns }}$ & 1.0 \\
\hline \multirow[t]{2}{*}{ Sophomore $^{\text {ns }}$} & Freshman $^{\mathrm{ns}}$ & .57 \\
\hline & Junior $^{\text {ns }}$ & .19 \\
\hline \multirow[t]{3}{*}{ Junior $^{\mathrm{ns}}$} & Freshman $^{\text {ns }}$ & .94 \\
\hline & Sophomore $^{\text {ns }}$ & .19 \\
\hline & Senior $^{\mathrm{ns}}$ & .99 \\
\hline Senior $^{\mathrm{ns}}$ & Freshman $^{\text {ns }}$ & .1 .0 \\
\hline
\end{tabular}

*Sig. At $\mathrm{P} \leq .003 . \mathrm{ns}=$ not significant 
Table D20. Tukey’s Post-hoc Test for Group Number 3 by Top 6 Primary Sport

\begin{tabular}{|c|c|c|}
\hline \multirow{3}{*}{$\begin{array}{l}\text { Variable } \\
\text { Football }^{\text {ns }}\end{array}$} & Variable & $\mathrm{P}$ \\
\hline & Basketball $^{\mathrm{ns}}$ & 1.0 \\
\hline & Softball $^{\text {ns }}$ & .69 \\
\hline \multirow[t]{4}{*}{ Soccer $^{\mathrm{ns}}$} & Football $^{\text {ns }}$ & .38 \\
\hline & Basketball $^{\mathrm{ns}}$ & .46 \\
\hline & Baseball $^{\mathrm{ns}}$ & 1.0 \\
\hline & Softball $^{\text {ns }}$ & 1.0 \\
\hline \multirow[t]{2}{*}{ Track $^{\text {ns }}$} & Football $^{\mathrm{ns}}$ & .55 \\
\hline & Soccer $^{\text {ns }}$ & 1.0 \\
\hline \multirow[t]{5}{*}{ Basketball $^{\text {ns }}$} & Football $^{\text {ns }}$ & 1.0 \\
\hline & Soccer ${ }^{\mathrm{ns}}$ & .46 \\
\hline & Track $^{\mathrm{ns}}$ & .60 \\
\hline & Baseball $^{\text {ns }}$ & .59 \\
\hline & Softball $^{\mathrm{ns}}$ & .71 \\
\hline \multirow[t]{4}{*}{ Baseball $^{\text {ns }}$} & Football $^{\text {ns }}$ & .55 \\
\hline & Soccer $^{\text {ns }}$ & 1.0 \\
\hline & Track $^{\text {ns }}$ & 1.0 \\
\hline & Basketball $^{\mathrm{ns}}$ & .59 \\
\hline \multicolumn{3}{|c|}{ *Sig. At $\mathrm{P} \leq .003 . \mathrm{ns}=$ not significant } \\
\hline \multicolumn{3}{|c|}{ Table D21. Tukey’s Post-hoc Test for Group Number 4 by Year in School } \\
\hline Variable & Variable & $\mathrm{P}$ \\
\hline \multirow[t]{3}{*}{ Freshman $^{\text {ns }}$} & Sophomore $^{\text {ns }}$ & .48 \\
\hline & Junior ${ }^{\text {ns }}$ & .43 \\
\hline & Senior $^{\mathrm{ns}}$ & .45 \\
\hline \multirow[t]{3}{*}{ Sophomore $^{\mathrm{ns}}$} & Freshman $^{\mathrm{ns}}$ & .48 \\
\hline & Junior $^{\text {ns }}$ & .01 \\
\hline & Senior $^{\mathrm{ns}}$ & .03 \\
\hline \multirow[t]{3}{*}{ Junior $^{\mathrm{ns}}$} & Freshman $^{\text {ns }}$ & .43 \\
\hline & Sophomore $^{\text {ns }}$ & .01 \\
\hline & Senior ${ }^{\text {ns }}$ & 1.0 \\
\hline \multirow[t]{3}{*}{ Senior $^{\mathrm{ns}}$} & Freshman $^{\text {ns }}$ & .45 \\
\hline & Sophomore $^{\text {ns }}$ & .03 \\
\hline & Juniorns & 1.0 \\
\hline
\end{tabular}


Table D22. Tukey’s Post-hoc Test for Group Number 4 by Top 6 Primary Sport

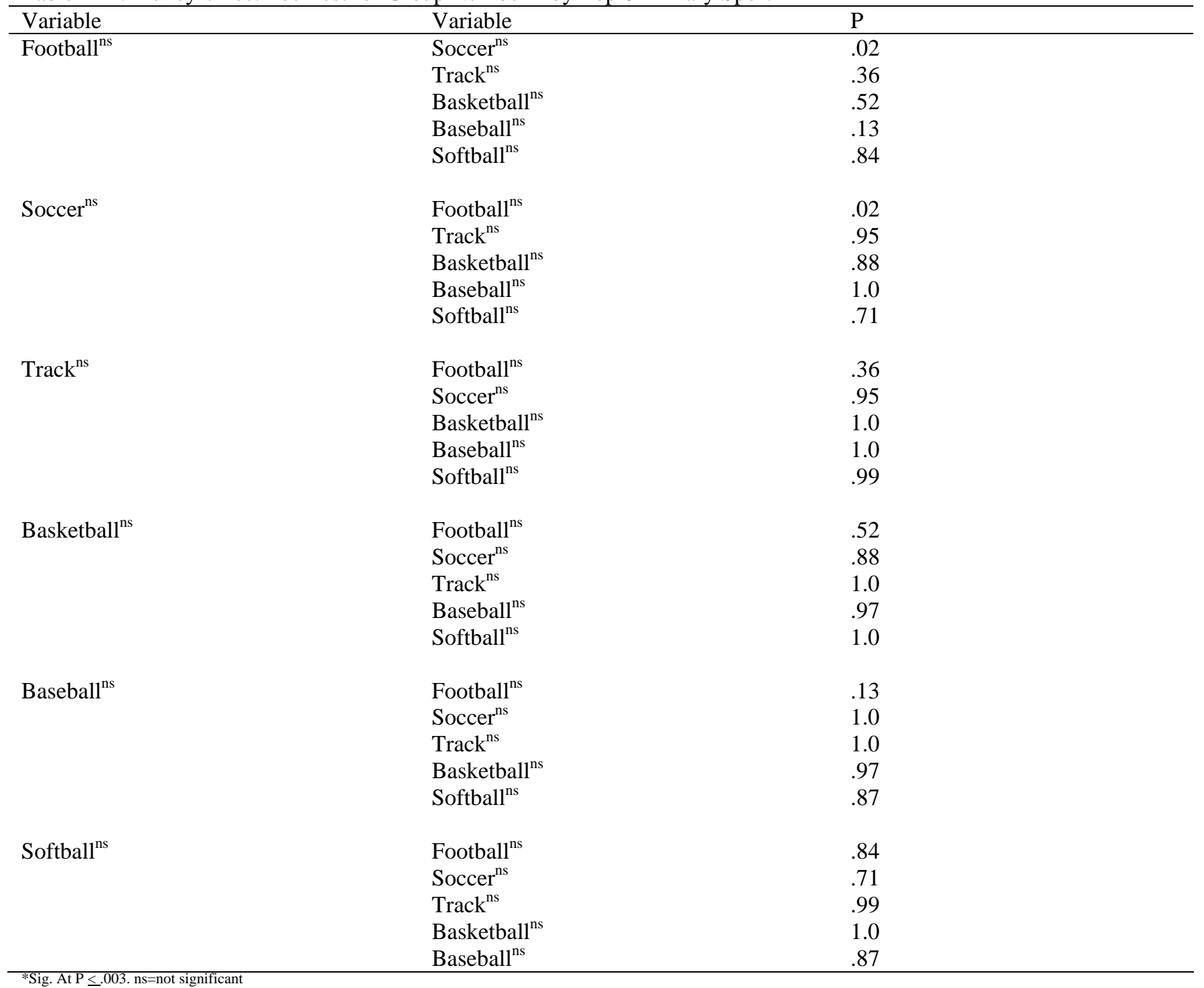

Table D23. Tukey's Post-hoc Test for Group Number 5 by Year in School

\begin{tabular}{|c|c|c|}
\hline Variable & Variable & $\mathrm{P}$ \\
\hline \multirow[t]{3}{*}{ Freshman $^{\text {ns }}$} & Sophomore $^{\text {ns }}$ & .99 \\
\hline & Junior $^{\text {ns }}$ & .51 \\
\hline & Senior $^{\mathrm{ns}}$ & .78 \\
\hline \multirow[t]{2}{*}{ Sophomore $^{\text {ns }}$} & Freshman $^{\text {ns }}$ & .99 \\
\hline & Junior $^{\text {ns }}$ & .70 \\
\hline \multirow[t]{3}{*}{ Junior $^{\text {ns }}$} & Freshman $^{\text {ns }}$ & .51 \\
\hline & Sophomore $^{\text {ns }}$ & .70 \\
\hline & Senior $^{\text {ns }}$ & .99 \\
\hline Senior $^{\mathrm{ns}}$ & Freshman $^{\mathrm{ns}}$ & .78 \\
\hline
\end{tabular}


Table D24. Tukey’s Post-hoc Test for Group Number 5 by Top 6 Primary Sports

\begin{tabular}{|c|c|c|}
\hline Variable & Variable & $\mathrm{P}$ \\
\hline \multirow[t]{5}{*}{ Football $^{\text {ns }}$} & Soccer $^{\text {ns }}$ & .06 \\
\hline & Track $^{\mathrm{ns}}$ & .97 \\
\hline & Basketball $^{\text {ns }}$ & .07 \\
\hline & Baseball $^{\mathrm{ns}}$ & .21 \\
\hline & Softball $^{\mathrm{ns}}$ & .11 \\
\hline \multirow[t]{5}{*}{ Soccer ${ }^{\mathrm{ns}}$} & Football $^{\text {ns }}$ & .06 \\
\hline & Track $^{\mathrm{ns}}$ & .49 \\
\hline & Basketball $^{\text {ns }}$ & 1.0 \\
\hline & Baseball $^{\text {ns }}$ & 1.0 \\
\hline & Softball $^{\text {ns }}$ & 1.0 \\
\hline \multirow[t]{5}{*}{ Track $^{\text {ns }}$} & Football $^{\text {ns }}$ & .97 \\
\hline & Soccer $^{\text {ns }}$ & .49 \\
\hline & Basketball $^{\mathrm{ns}}$ & .46 \\
\hline & Baseball $^{\text {ns }}$ & .70 \\
\hline & Softball ${ }^{\mathrm{ns}}$ & .52 \\
\hline \multirow[t]{5}{*}{ Basketball $^{\text {ns }}$} & Football $^{\text {ns }}$ & .07 \\
\hline & Soccer ${ }^{\mathrm{ns}}$ & 1.0 \\
\hline & Track $^{\mathrm{ns}}$ & .46 \\
\hline & Baseball $^{\text {ns }}$ & 1.0 \\
\hline & Softball $^{\text {ns }}$ & 1.0 \\
\hline \multirow[t]{5}{*}{ Baseball $^{\mathrm{ns}}$} & Football $^{\mathrm{ns}}$ & .21 \\
\hline & Soccer $^{\text {ns }}$ & 1.0 \\
\hline & Track $^{\mathrm{ns}}$ & .70 \\
\hline & Basketball $^{\text {ns }}$ & 1.0 \\
\hline & Softball $^{\text {ns }}$ & 1.0 \\
\hline \multirow[t]{5}{*}{ Softball $^{\mathrm{ns}}$} & Football $^{\mathrm{ns}}$ & .11 \\
\hline & Soccer ${ }^{\text {ns }}$ & 1.0 \\
\hline & Track $^{\text {ns }}$ & .52 \\
\hline & Basketball $^{\text {ns }}$ & 1.0 \\
\hline & Baseball $^{\text {ns }}$ & 1.0 \\
\hline
\end{tabular}




\section{APPENDIX E}

\section{SUGGESTIONS FOR FURTHER RESEARCH}

1. Repeat this study using a larger number of high school student-athletes at different high schools in different locations (rural, metropolitan, suburban, inner city).

2. Repeat this study looking at ethnicity.

3. Test the nutrition knowledge of the coaches.

4. Test the nutrition knowledge of the physical education teachers.

5. Test and compare nutrition knowledge of non-athletes to athletes.

6. Modify the questionnaire based on subjects responses.

7. Modify questionnaire so there are the same number of questions in each group and compare responses for each group.

8. Test the nutrition knowledge of the parents/family of the athletes.

9. Have the athletes do a dietary recall to observe eating habits and correlate with the questionnaire. 


\section{ADDITIONAL REFERENCES}

24. Merriam-Webster Online Dictionary. www.m-w.com/cgi-bin/diction. Accessed website April 7, 2004.

25. Boyle MA. Community Nutrition in Action: An Entrepreneurial Approach. $3^{\text {rd }}$ Ed. Belmont, California. Wadsworth Publishing. 2003. 322-325.

26. Consumer information center: the food guide pyramid. http://www.pueblo.gsa.gov/cic text /food/food-pyramid/main.htm. Accessed website September 13, 2003.

27. Anderson JJB, Anderson TW. Nutritional guidelines for injury prevention in school athletes. J Physic Educ Rec Dance. 1993; 76-82.

28. Berning JR, Nelson Steen S. Nutrition for sports and exercise. $2^{\text {nd }}$ Ed. 1998. Gaithersburg, Md. Aspen Publication. 21-107

29. Clark N. Nancy Clark's sports nutrition guidebook: eating to fuel your active lifestyle. 1990. Champaign, Ill. Leisure Press.1-157.

30. American Dietetic Association, Dietitians of Canada, and the American College of Sports Medicine. Position of the american dietetic association, dietitians of canada, and the american college of sports medicine:nutrition and athletic performance. J Am Diet Assoc. 2000;110(12):1543-1556.

31. Casa DJ, Armstrong LE, Hillman SK, Montain SJ, Reiff RV, Rich BSE, Roberts WO, Stone JA. National athletic trainers' association position statement: fluid replacement for athletes. J Athl Train 2000;35(2):212-224.

32. Convertino VA, Armstrong LE, Coyle EF, Mack GW, Sawka MN, Senay LC, Sherman WM. American college of sports medicine position stand: exercise and fluid replacement. Med Sci Sports Exerc. 1996;28(1): i-vii

33. Perko M, Bartee RT, Dunn MS, Qi Wang M, Eddy J. Giving new meanings to the term "taking one for the team": Influences on the use/non-use of dietary supplements among adolescent athletes. Am J Health Sci. 2000;16(2):99-107.

34. Corley G, Demarest-Litchford M, Bazzarre TL. Nutrition knowledge and dietary practices of college coaches. J Am Diet Assoc. 1990;(90)5:705-709.

35. Rockwell MS, Nickols-Richardson SM, Thye FW. Nutrition knowledge, opinions, and practices of coaches and athletic trainers at a division I university. J Sport Nut Exer Metab. 2001;11:174-185.

36. Baer JT, dean DJ, Lambrinides T. How high school football coaches recommend their players gain lean body mass. J Strength Cond Res 1994;8(2):72-75 
37. Sossin K, Gizis F, Marquart LF, Sobal J. Nutrition beliefs, attitudes, and resource use of high school wrestling coaches. Int J Sport Nut. 1997;7:219-228.

38. Graves KL, Farthing MC, Smith SA, Turchi JM. Nutrition training, attitudes, knowledge, recommendations, responsibility, and resource utilization of high school coaches and trainers. J Am Diet Assoc. 1991;91:321-324.

39. Bedgood BL, Tuck MB. Nutrition knowledge of high school athletic coaches in Texas. J Am Diet Assoc. 1983;83(6):672-677

40. Cho M, Fryer BA. Nutrition knowledge of collegiate physical education majors. J Am Diet Assoc. 1974; 65:30-34. 